\title{
Yalova Üniversitesi Merkez Kampüsünde Elektrik Enerji Kalitesini Etkileyen Harmoniklerin İncelenmesi
}

\author{
Aykut Fatih GÜVEN ${ }^{1 *}$, Nuran YÖRÜKEREN ${ }^{2}$ \\ ${ }^{1}$ Yalova Üniversitesi, Mühendislik Fakültesi, Enerji Sistemleri Mühendisliği Bölümü, Yalova, Türkiye \\ ${ }^{2}$ Kocaeli Üniversitesi, Mühendislik Fakültesi, Elektrik Mühendisliği Bölümü, Kocaeli, Türkiye
}

"Sorumlu Yazar: afatih.guven@yalova.edu.tr

Geliş Tarihi: 19.04 .2019

Kabul Tarihi: 28.05 .2019

\section{$\ddot{O} z$}

Elektrik güç sistemlerinde enerjinin üretilmesi, iletimi ve dağıtımı sırasında, akım ve gerilimin, $50 \mathrm{~Hz}$ frekansında ve sinüs eğrisine çok benzer bir biçimde olması arzu edilir. Bu koşul, elektrik enerjisinin kalitesini belirleyen ana faktörlerden biridir. Ancak, doğrusal olmayan yüklerin ürettiği harmonikler nedeni ile akım ve gerilim gibi büyüklükler sinüs biçimde olmaktan çıkarlar ve dalga biçimleri oldukça karmaşık hale gelir. Bunun sonucunda, işletme açısından arzu edilmeyen önemli sorunlar ortaya çıkar. Bu problemler, sistemin çalışmasını olumsuz yönde etkileyen ve tüketiciye kaliteli enerji sunulmasını engelleyen problemlerdir. Bu çalışmada, Yalova Üniversitesi Merkez Kampüsünde tüketilen elektrik enerjisinin kalitesi incelenmiştir. Çalışma kapsamında, Merkez kampüsünde farklı noktalardaki güç dağıtım merkezlerine güç kalitesi analizörü bağlanmıştır. Güç kalitesi analizörü ile sisteme ait akım, gerilim, güç ve frekans gibi parametrelerin yanı sıra sistemde meydana gelen güç kalitesi olayları ölçülmüş ve bilgisayar ortamına aktarılarak incelenmiştir. Harmonik ölçümleri sonucunda elde edilen veriler doğrultusunda güç kalitesi problemlerinin sebepleri araştırılarak çözüm önerileri sunulmuştur

Anahtar Kelimeler: Güç Sistemleri, Enerji Kalitesi, Harmonik, Harmonik Bozulma.

\section{Investigation of Harmonics Affecting the Electrical Energy Quality in Yalova University Main Campus}

\begin{abstract}
During the generation, transmission, and distribution of energy in electric power systems, it is desirable that the current and the voltage are in a frequency of $50 \mathrm{~Hz}$ and very similar to the sine curve. This condition is one of the main factors determining the quality of electric energy. However, due to the harmonics produced by the nonlinear loads, the magnitudes such as current and voltage are subtracted from the sinusoidal form and the waveforms become more complex. As a result, important problems arise which are not desirable in terms of operation. These problems are problems that adversely affect the operation of the system and prevent the transmission of high quality energy to the consumer. In this study, quality of electrical energy consumed on Yalova University Central Campus was investigated. Within the scope of the study, Power quality analyzers were connected to power distribution centers at different points on the central campus. In addition to the parameters such as current, voltage, power and frequency of the system with the power quality analyzer, power quality events that occurred in the system were measured and analyzed by transferring them to the computer environment. In accordance with the data obtained as a result of harmonic measurements, the reasons for power quality problems were investigated and solution proposals were presented. As well as the parameters such as the current, voltage, power and frequency of the system, power quality events occurring in the system were measured and sent to a computer for analyses. Some solutions were suggested by investigating the causes of power quality disturbances in accordance with the data obtained.
\end{abstract}

Keywords: Power Systems, Energy Quality, Harmonic, Harmonic Distortion. 


\section{Giriş}

Günümüzde elektrik enerjisi kaynaklarının azalması ve enerji fiyatlarının sürekli artması elektrik enerjisinin daha verimli bir şekilde kullanılmasını zorunlu hale getirmiştir. Bunun bir sonucu olarak şebekeden sağlanan elektrik enerjisi bilgisayar, fax makinesi, fotokopi makinesi gibi birçok yüke güç elektroniği (güç konverterleri) devre elemanları vasıtasıyla yükün ihtiyaçlarını karşılayacak şekle (istenilen gerilimi, frekans ve akım değerlerine) dönüştürülmektedir. Teknolojinin gelişmesiyle birlikte elektrik enerjisi hayatımızın her alanında, hem endüstriyel bazda hem ticari bazda ve hem de meskenlerde çok yaygın olarak tüketilmektedir. Günümüz yük tiplerinin birçoğunun mikroişlemci tabanlı olduğu görülmektedir. Mikroişlemci tabanlı yüklerin hem çok kaliteli bir enerjiyle beslenmesi ve hem de aynı zamanda (kullandıkları anahtarlamalı konverterlerden dolayı) güç kalitesi problemlerinin kaynağını oluşturmaması beklenmektedir. Bu tür yükler genelde nonlineer yükler veya devre elemanları olarak tanımlanırlar. Doğrusal olmayan yüklerin geniş bir şekilde kullanılması, elektrik güç sistemlerinde güç kalitesi problemine özellikle harmonik kirliliğine sebep olmaktadır. Bunun sonucu olarak tüketiciye verilen enerjinin kalitesi önemli ölçüde olumsuz olarak etkilenmektedir. Harmoniklerin meydana getirdiği etkilere; enerji hatlarındaki kayıpların artması, elektronik-tabanlı kontrol sistemlerinin hatalı çalışması, enerji hatlarının yakınından geçen haberleşme sistemlerinin olumsuz yönde etkilenmesi, elektrik makinelerinde aşırı ısınma, gürültülü çalışma ve mekanik salınımlar vb. gibi birçok problem örnek olarak verilebilir.

Güç kalitesine olan ilgi de her geçen gün daha da artmaktadır. Bunun nedeni olarak pek çok parametre sıralanabilir; elektroniğin gelişmesiyle hassas yüklerin sayısının artması, hassas yüklerin, gerilim dalgalanmalarından ve harmoniklerden olumsuz etkilenmesi, hatalı çalışması veya arızalanması, standardizasyon ve performans kriterlerinin önem kazanması, ekipmanların her geçen gün dalgalanmalara daha da hassasiyet göstermeleri, Değişken Hız Kontrol Cihazları gibi yeni teknolojik cihazların dalgalanmalara sebep olmaları, güç kalitesi izleme cihazlarının hızla gelişmesi, enerji sektöründe rekabetin artması ve kullanıcıların daha kaliteli enerji talep etmeleridir.

Güç kalitesi problemlerinin tespit edilmesi, sebeplerinin belirlenmesi ve muhtemel sonuçlarının ortaya çıkarılması ve analiz çalışmaları için elektrik enerjisinin üretim noktasından tüketim noktasına kadar üzerinde önemle durulması gerekmektedir.

$\mathrm{Bu}$ çalışmada Yalova Üniversitesi için güç kalitesi ölçümleri yapılmıştır. Yalova Üniversitesinde kullanılan yük tiplerine bakıldığında büyük çoğunluğunun nonlineer yük tipleri olduğu görülmektedir. Gerek akademik gerekse idari personelin kullandığı bilgisayarlar, fotokopi makineleri, fax cihazları, bölüm laboratuvarlarında bulunan cihazlar, merkezi araştırma laboratuvarında farklı amaçlarla kullanılan yüksek güçte cihazlar doğrusal olmayan yüklere örnek olarak verilebilir. $\mathrm{Bu}$ tip cihazların çok kaliteli elektrik enerjisiyle beslenmesi gerekmektedir. 
Özellikle dalga şekli bozulmuş enerjiyle beslenmeleri cihazların bozulmasına neden olmaktadır. Bilgi işlem merkezinde veya strateji dairesinde verilerin kayıtlı olduğu bilgisayarların güç beslemesinde meydana gelebilecek bir dalgalanma, istenmeyen sonuçlar doğurabilir. Öğrenci kayıtlarının saklandığı bilgisayarlarda veri kaybı probleminin oluşması istenmemektedir. Bu çalışma, bu tür muhtemel kayıpların önceden önlenmesini hedeflemektedir. Çalışma kapsamında merkez kampüsteki enerji altyapısını olumsuz olarak etkileyen güç kalitesi harmonik bozulmalara yol açan problemlerin araştırılması, kesintilerin sebeplerinin tespiti ve asgari düzeye indirmek için gerekli önlemlerin alınması hedeflenmektedir.

Bir güç sisteminin güç kalitesi problemlerini tanımlamak, güç kalitesini değerlendirmek ve çözüm önerileri ortaya koymak için IEEE, IEC, ANSI, CBEMA, EPRI gibi farklı çalışma grupları farklı standartlar oluşturmuşlardır. Dünyada güç kalitesi çalışmalarında genellikle IEEE ve IEC standartları tercih edilmektedir. (Kesler, 2010)

IEEE 1159 standartlarına göre güç kalitesi problemleri; Geçici dalgalanma (Transients Surges), Kısa süreli değişimler (Short duration variations), Uzun süreli değişimler (Long duration variations), Dalga şekli bozulmaları (Waveform distortion), Gerilim dengesizliği (Voltage unbalance), Frekans değişimleri (Power frequency variations), Gerilim kırpışması (Voltage flickers) olmak üzere yedi kategoriye ayrılmaktadır. (Kesler, 2010)

Geçici dalgalanma, darbeli (impulsive transients) ve salınımlı (oscillatory transients) olarak iki şekilde oluşmaktadır. Darbe etkisi, güç sistem hatlarında akım veya gerilim üzerinde çok kısa anlık bir değişim olarak tanımlanmaktadır. Kısa süreli değişimler, güç sistemlerinde gerilimin genliğinde veya akımda 0,5 çevrim ile 1 dakika arasında meydana gelen değişim olaylarıdır. $\mathrm{Bu}$ sorun, IEC standardında gerilim çökmeleri “voltage dips" ve kısa süreli kesintiler "short interruptions" olarak iki başlıkla sınıflandırılmaktadır. Uzun süreli değişimler, güç sistemlerinde gerilim genliğinde veya akımda 1 dakikadan uzun süreli meydana gelen değişim olayları olarak tanımlanmaktadır.

Güç sistem hatlarında şebeke frekansının ve sinüzoidal dalga şeklinin bozulmasına neden olan olaylar bir güç kalitesi problemi olarak ifade edilmektedir. Bu olaylar, doğru akım bileşeni (DC offset), harmonikler (harmonics), ara harmonikler (interharmonics), çentikler (notching) ve gürültü (EMI/ noise) olarak sınıflandırılmaktadırlar. Gerilim dengesizliği, üç faz gerilim veya akımın ortalamasından elde edilen maksimum sapma veya üç faz gerilim veya akımın ortalamasına bölümü olarak, frekans değişimleri ise güç sisteminin temel frekansının nominal değerinden sapması olarak tanımlanmaktadırlar. Gerilim kırpışması, genliği nominal gerilimin 0.9-1.1p.u. değerleri arasında olan hızlı sistematik gerilim değişiklikleridir.

Harmonikler güç kalitesinin en önemli ölçülebilir parametrelerinden biridir. Harmonikler, genel olarak nonlineer elemanlar ile nonsinüsoidal kaynaklardan herhangi birisi veya bunların ikisinin 
sistemde bulunmasından meydana gelirler. Akım-gerilim karakteristiği doğrusal olmayan elemanlara nonlineer elemanlar denir. Sistemde bulunan bu elemanların etkisiyle akım ve gerilim dalga biçimleri, periyodik olmakla birlikte temel sinüsoidal dalga ile frekans ve genliği farklı diğer sinüsoidal dalgaların toplamından meydana gelmektedir. Temel dalga dışındaki sinüsoidal dalgalara "harmonik" ad1 verilir. (Kürker, 2016)

Güç sistemindeki sinüsoidal dalganın simetrisinden dolayı 3., 5., 7., 11. gibi tek harmonik bileşenleri bulunur. Çift harmonikli bileşenler bulunmaz.

Enerji kalitesinin ölçülebilmesi ve bozulmaların sınırlandırılabilmesi için akım ve gerilim harmoniklerinin tanımlanması gerekmektedir.

Toplam harmonik distorsiyonu (THD), harmonikli bileşenlerin efektif(rms) değerlerinin, temel bileşen efektif (rms) değerine bölünmesiyle elde edilir ve genellikle yüzde olarak gösterilir. Toplam harmonik distorsiyon ifadesinin yardımı ile temel sinüs bileşenimizin harmonik bileşenlerin toplanması ile ilk formundan ne derece sapmaya maruz kalacağı görülebilir. (Kürker, 2016)

Sadece temel frekanstan oluşan tam bir sinüsoidal dalga için THD değeri sıfırdır. Yani denklem (1) ve denklem (2)'den de anlaşılacağı gibi harmonik bileşenlerin olmadığı sistemlerde toplam harmonik distorsiyon herhangi bir değere ulaşmayacaktır. Gerilim için toplam harmonik distorsiyonu denklem (1)'de verilmiştir. (Kürker, 2016)

$\mathrm{THD}_{\mathrm{V}}=\mathrm{U}_{\mathrm{THD}}=\frac{\sqrt{\sum_{\mathrm{n}=2}^{\infty} \mathrm{V}_{\mathrm{n}}^{2}}}{\mathrm{~V}_{1}}=\frac{\sqrt{\mathrm{V}_{2}+\mathrm{V}_{3}+\mathrm{V}_{4}+\cdots+\mathrm{V}_{\mathrm{n}}}}{\mathrm{V}_{1}}$

Burada;

$\mathrm{THD}_{\mathrm{V}}=$ Gerilimin toplam harmonik distorsiyonunu (bozunumu),

$\mathrm{V}_{\mathrm{n}}$ : Devreye uygulanan gerilimin n'inci mertebedeki harmoniğinin etkin değerini,

$\mathrm{V}_{1}$ : Devreye uygulanan gerilimin temel frekanstaki etkin değerini,

Akım için toplam harmonik distorsiyonu denklem (2)'de verilmiştir.

$\mathrm{THD}_{\mathrm{I}}=\mathrm{I}_{\mathrm{THD}}=\frac{\sqrt{\sum_{\mathrm{n}=2}^{\infty} \mathrm{I}_{\mathrm{n}}^{2}}}{\mathrm{I}_{1}}=\frac{\sqrt{\mathrm{I}_{2}+\mathrm{I}_{3}+\mathrm{I}_{4}+\cdots+\mathrm{I}_{\mathrm{n}}}}{\mathrm{I}_{1}}$

$\mathrm{THD}_{\mathrm{I}}$ : Akımın toplam harmonik distorsiyonunu (bozunumu),

$\mathrm{I}_{\mathrm{n}}$ : Devreden geçen akımın n'inci mertebedeki harmoniğinin etkin değerini,

$\mathrm{I}_{1}$ : Devreden geçen akımın temel frekanstaki etkin değerini ifade etmektedir,

Temel dalga, harmonikli dalgalar ve bunların bileşkesi olan toplam dalgalar ile ilgili örnek şekil 1' de gösterilmiştir. 


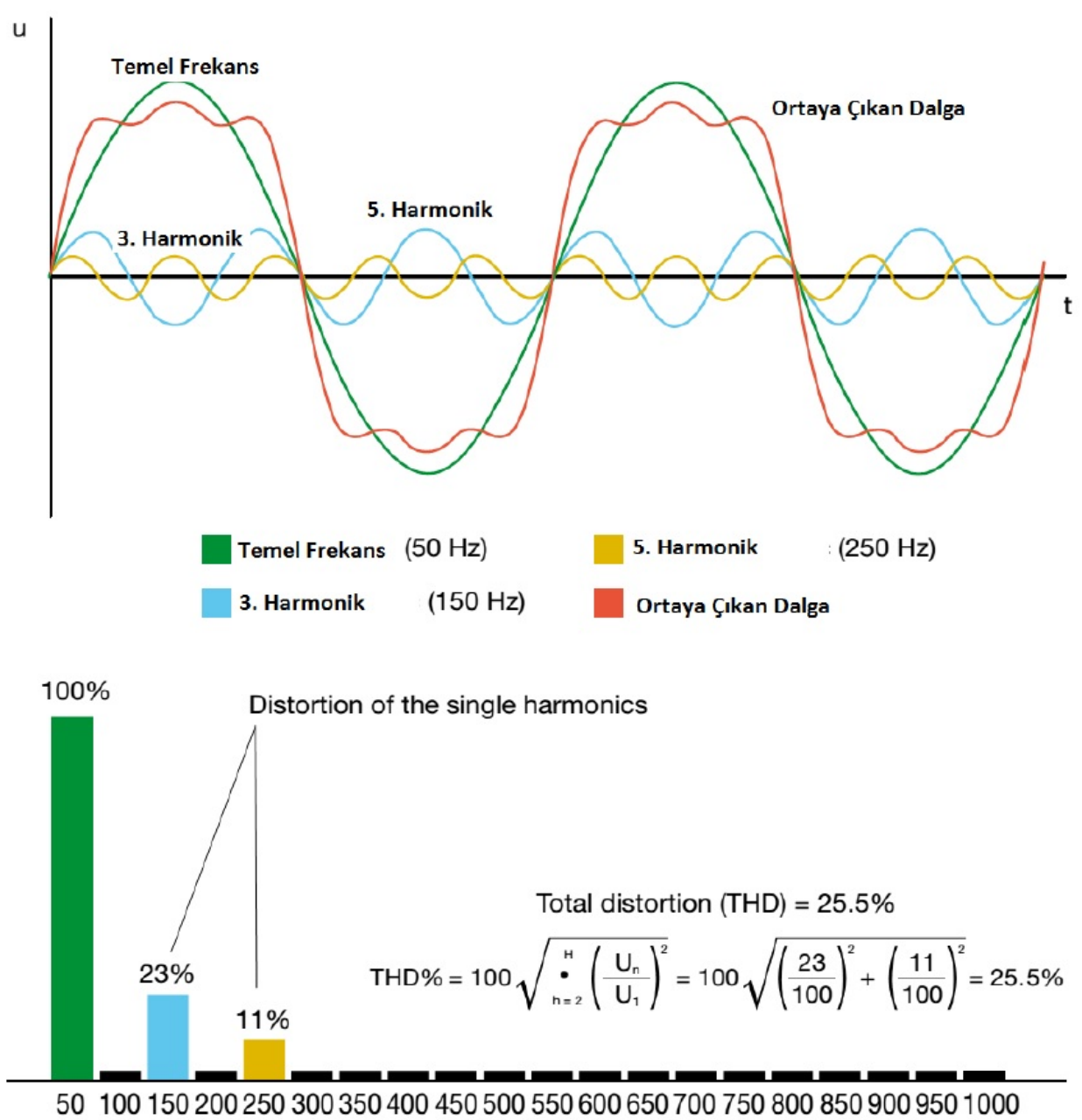

Şekil 1. Harmoniklerin sisteme etkisi, sinüsoidal bozukluk (harmonik bozulmasında bir akım dalgası), temel $50 \mathrm{~Hz}$. sinüsoidal akım, 3.,5. harmonik ve toplam harmonikli dalga . (Kürker, 2016)

Ülkemizde ideal enerji dağıtımı $50 \mathrm{~Hz}$. de, temel frekansta ve sinüsoidal dalga şeklindedir. Ancak işletmelerimizdeki bazı yükler sahip oldukları çalışma karakteristiklerinden dolayı çeşitli frekans seviyelerinde akım ve gerilim oluştururlar. $\mathrm{Bu}$ gibi devrelerde faz gerilimlerinin dengeli olması ve gerilimdeki harmonik miktarının belirli değerlerde kalması gibi bir takım kriterlerin göz önüne alınması gerekir. (Kürker, 2016)

Uluslararası (IEC 519-1992)'ye göre harmonik bozulma değerleri akım için $\mathrm{I}_{\mathrm{THD}}<\% 5$ ve gerilim için $\mathrm{U}_{\mathrm{THD}}<\% 3$ verilmiştir. Şebekede normal olarak akım toplam harmonik distorsiyonu $\mathrm{I}_{\mathrm{THD}}<\% 15-20$ ve gerilim toplam harmonik distorsiyonu $\mathrm{U}_{\mathrm{THD}}<\% 3-5$ olmalıdır. $\mathrm{Bu}$ limit değerlerinin üzerinde bulunan harmonik oranlarında elektrik devre veya sistemleri için tehlikeli ve büyük zararlar oluşturabilecektir. (Kürker, 2016) 


\section{Materyal ve Metot}

Yalova Üniversitesinin elektrik enerjisi besleme şeması Şekil 1'de görülmektedir. Kampüsün ana beslemesi $154 \mathrm{kV}$ gerilim ile yapılmaktadır. Ana beslemeden gelen $154 \mathrm{kV}$ 'luk gerilim bir adet 50MVA transformatör ile 34,5 kV'a düşürülmektedir. Kampüs içinde bulunan ana binalar (Rektörlük, Mühendislik Fakültesi, Araştırma Laboratuvarı) 34,5 kV enerji ile beslenmekte ve her binanın besleme gerilimi kendisine ait bir transformatör ile 380/220 Volt gerilime indirgenmektedir. Her binanın kendisine ait dizel jeneratör tipi bir kesintisiz güç kaynağ 1 mevcuttur. Rektörlük binasında 525 kVA dizel jeneratöre ek olarak bir adet 120 kVA'llk on-line KGK, Mühendislik Fakültesi binasında 200 kVA dizel jeneratöre ek olarak bir adet 80 kVA'lık on-line KGK ları bulunmaktadır. Araştırma Merkez Laboratuvarlarında ise 200 kVA dizel jeneratöre ek olarak 200 kVA'lık on-line KGK hizmet vermektedir. Bu kesintisiz güç kaynakları ile binadaki belirli hassas yükler beslenmesi için düşünülmüştür, Dizel jeneratörlerin tepki süresi 10 saniye olarak ayarlanmıştır. Her binanın kendisine ait kompanzasyon ünitesi mevcuttur. Her kompanzasyon ünitesi 18 kademeli bir röle ile kontrol edilmektedir. Transformatörlerin anma güçleri, kompanzasyon kapasiteleri ve KGK'ların kapasitesi Tablo 1'de verilmektedir.

Tablo 1. Transformatör Yük Değerleri

\begin{tabular}{|c|c|c|c|c|}
\hline Bina Ad 1 & $\begin{array}{l}\text { Transfo } \\
\text { rmatör } \\
\text { Gücü }\end{array}$ & $\begin{array}{c}\text { Kompanzasyon } \\
\text { Kapasitesi }\end{array}$ & $\begin{array}{c}\text { Kesintisiz Güç } \\
\text { Kaynağ1 } \\
\text { Kapasitesi }\end{array}$ & Bağlantı Grupları \\
\hline Rektörlük & $\begin{array}{l}1250 \\
\mathrm{kVA}\end{array}$ & $400 \mathrm{kVAr}$ & $120 \mathrm{kVA}$ & Dyn11 \\
\hline $\begin{array}{l}\text { Mühendislik } \\
\text { Fakültesi }\end{array}$ & $\begin{array}{l}1600 \\
\mathrm{kVA}\end{array}$ & 396 kVAr & 80 kVA & Dyn11 \\
\hline $\begin{array}{c}\text { Araştırma } \\
\text { Laboratuvarı }\end{array}$ & $\begin{array}{l}1600 \\
\mathrm{kVA}\end{array}$ & $600 \mathrm{kVAr}$ & $200 \mathrm{kVA}$ & Dyn11 \\
\hline
\end{tabular}

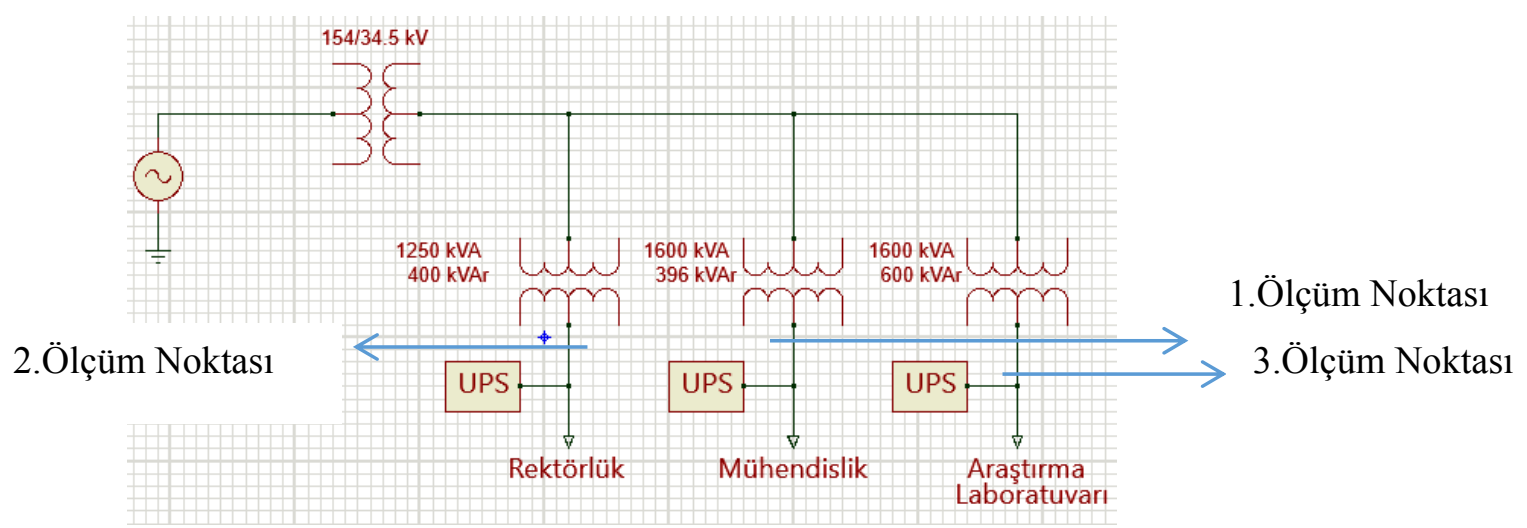

Şekil 2. Kampüs Besleme Şemas1 
Yapılan saha çalışmalarında toplanan verilerin toplanma şekli ve raporlama şekli çok önemlidir. Toplanan veriler cihazdan cihaza farklılıklar gösterebilir. Farklı cihazlarla yapılan ölçümlerin aynı sonucu vermesi için 2003 yılında IEC 61000-4-30 standardı yayınlandı. Bu standart güç kalitesi izlenmesini ve ölçülmesini düzenlemektedir. Standardın yayın tarihinden sonra üretilen güç kalitesi cihazları standartla uyumlu olarak üretilmektedirler.

Güç sistemlerinde kullanılan ölçüm cihazlarının gelişmesiyle birlikte en etkili ölçüm metodu, güç analizörünün kullanılmasıdır. Yalova Üniversitesi Merkez Yerleşkesinde güç kalitesi sorunlarının tespiti ve analiz çalışmalarında Fluke 435-II Üç Fazlı Enerji ve Güç Kalitesi Analizörü (GKA) kullanılmıştır. Çalışmada gerekli ölçümlerin yapılabilmesi için kullanılan Fluke435-II GKA ile güç sistemlerinde gerilim, akım, frekans, güç katsayısı, aktif güç, reaktif güç, harmonik distorsiyon değerleri anlık olarak ölçülerek kaydedilmektedir. Bu sayede güç sisteminin karakteristik analizi yapılabilmektedir. Fluke 435-II GKA, güç dağıtım sistemlerinin kontrolü için kapsamlı ve güçlü bir ölçüm seti sunmaktadır. Fluke 435-II GKA, Kırpışma, Geçici Akımlar, Güç Dalgası, Ana Şebeke Sinyali, Dalga Olayı, Rms Olayı ve \% 0,1 gerilim giriş hassasiyeti gibi ek özelliklere sahiptir. (Fluke Corporation, 2012)

Şekil 3'de Fluke 435-II GKA'nın resmi ve üç fazlı şebekeye bağlantısı verilmiştir. Bir GKA ekranındaki tüm ölçüm değerleri kaydedilebilmektedir. Ortalama, minimum ve maksimum değerler, ölçümün gerçekleştirildiği süre boyunca ayarlanabilir bir ortalama süreyle (1s) kaydedilebilmektedir. Ortalama süre ayarlanabildiği gibi toplam ölçüm ve başlangıç gecikmesi süresi de ayarlanabilmektedir. Ölçüm sonucu elde edilen veriler SD karta Measurement xx (Ölçüm xx) olarak kaydedilebilmektedir. LOGGER (Kayıt Cihazı) tuşunun altında maksimum 150 değer saklanabilmektedir. Kaydedilecek değer veya seti kullanıcı tarafindan tanımlanabilmektedir.
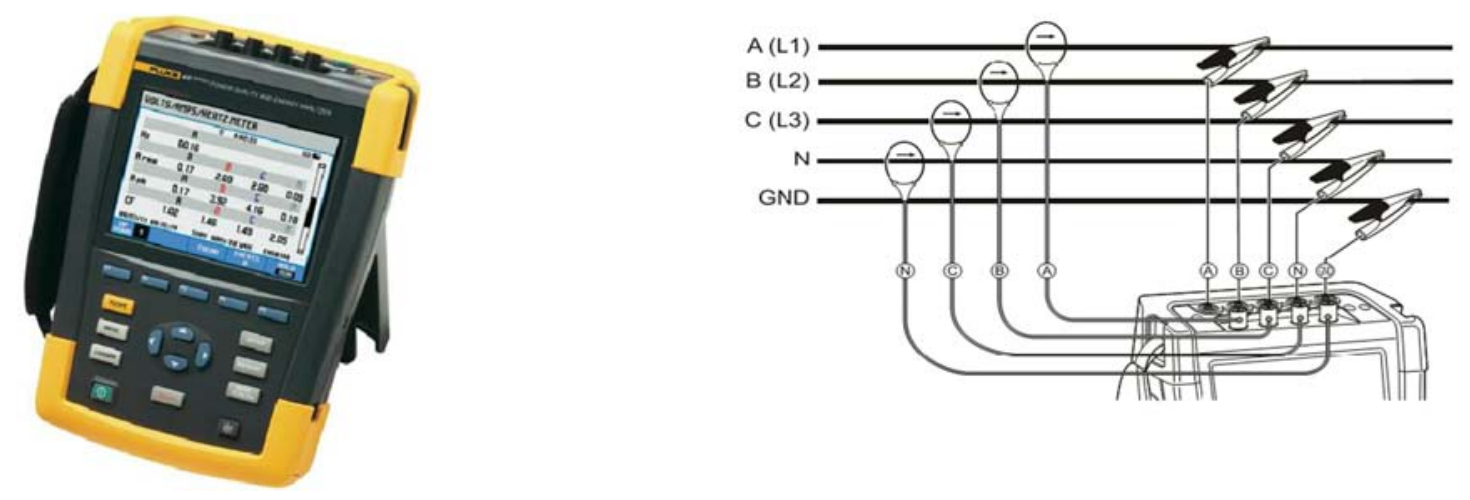

Şekil 3. FLUKE 435-II Üç fazlı Güç Kalitesi Analizörü ve Üç Fazlı GKA’nın Şebeke Bağlantısı

Yapılan saha çalışması kapsamında üniversite kampüsünde bulunan Rektörlük- Mühendislik Fakültesi ve Araştırma Laboratuvarına Şekil 4' de görüldüğü gibi Güç kalitesi analizörü bağlanarak besleme geriliminde meydana gelen dalgalanmalar kaydedilmiştir 


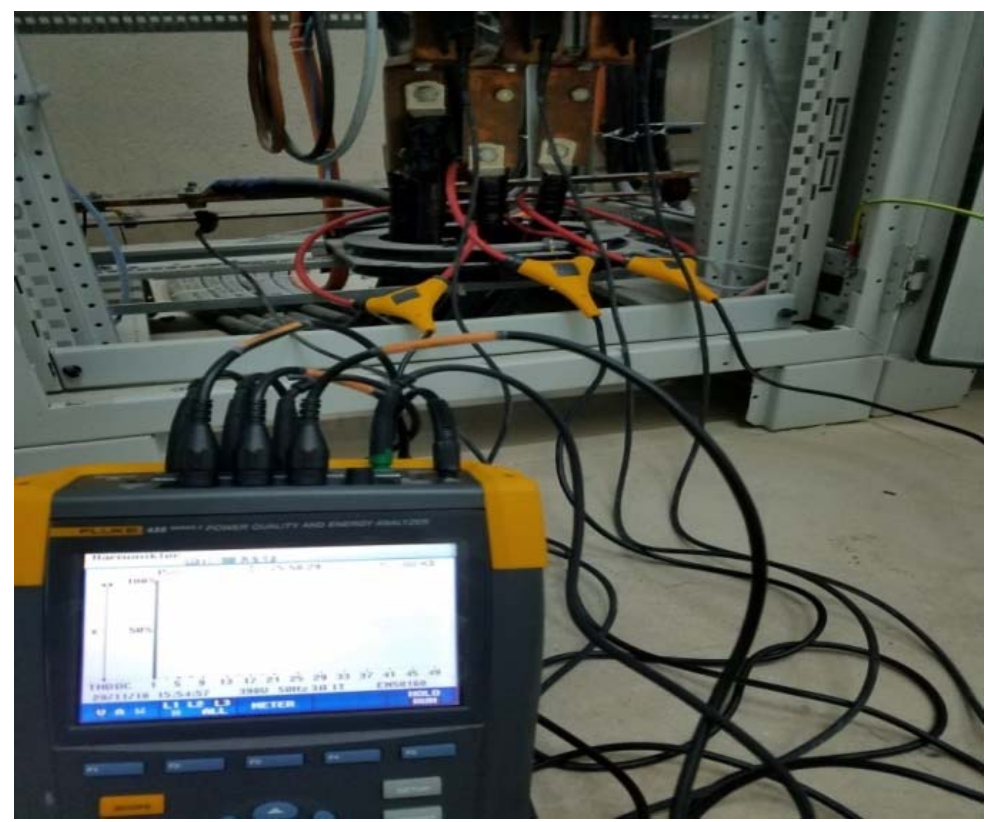

Şekil 4. Birincil Ölçüm Noktası (Mühendislik Fakültesi )

\section{Bulgular ve Tartışma}

Yapılan ölçümler neticesinde alınan veriler Power Log isimli programda incelenmiştir. Kampüs içerisinde bulunan 3 binanın farklı zaman aralıklarında GKA kullanılarak güç kalitesi ölçümleri değerlendirilmiştir. Yapılan tüm ölümlerde RMS kaydı, frekans kaydı, harmonik kaydı ve güç harmoniği kaydı ve voltaj-akım kaydı yapılmıştır. Araştırma Merkez Laboratuvarında yapılan kayıtlarda 2 adet düşme, 3 adet geçici olay, 1 adet kesinti olayı, 15 adet dalga olayı, 15 adet RMS olayı belirlenmiştir.

Mühendislik Fakültesinde yapılan kayıtlarda 9 adet düşme, 17 adet geçici olay, 62 adet dalga olayı, 62 adet RMS olayı belirlenmiştir.

Tablo 2 ve Şekil 7-8-9-10-11-12'de görüldüğü gibi 2.Ölçüm noktasında (Rektörlük binası) yapılan ölçümlerin her fazına ait gerilim ve akımların toplam harmonik değerleri verilmiştir. A, B ve C faz gerilimlerde oluşan THD uygun sınırlarda olmakla birlikte Tablo 2' de ortalama \% 1.34 civarında harmonik gerilim distorsiyonu olduğu görülmektedir. Şekil10-11-12'de görüldüğü gibi ortalama A fazının akım THD \%14.2, B fazının akım THD \%18.5 ve C fazının akım THD \%20.6 gibi büyük değerlerde olduğu gözlemlenmiştir. Ayrıca Şekil 5-6 'da A, B ve C fazlarına ait akım harmonik ve akım THD değerleri ile gerilim harmonik ve gerilim THD değerleri verilmiştir. 
Tablo 2. Rektörlük THDV ve THDI Ölçüm Sonuçları

\begin{tabular}{|c|c|c|c|c|c|c|c|}
\hline Tarih & Zaman & $\mathrm{THD}_{\mathrm{V}} \mathrm{AB}$ & $\mathrm{THD}_{\mathrm{V}} \mathrm{BC}$ & $\mathrm{THD}_{\mathrm{V}} \mathrm{CA}$ & $\mathrm{THD}_{\mathrm{I}} \mathrm{A}$ & $\mathrm{THD}_{\mathrm{I}} \mathrm{B}$ & $\mathrm{THD}_{\mathrm{I}} \mathrm{C}$ \\
\hline 23.11 .2018 & $10: 50: 07.711$ & 1,37 & 1,34 & 1,46 & 16,33 & 19,38 & 20,69 \\
\hline 23.11 .2018 & $11: 10: 47.711$ & 1,4 & 1,36 & 1,47 & 15,75 & 17,48 & 21,3 \\
\hline 23.11 .2018 & $13: 03: 57.711$ & 1,2 & 1,27 & 1,23 & 16,32 & 20,48 & 22,56 \\
\hline 23.11 .2018 & $20: 34: 17.711$ & 1,11 & 1,21 & 1,2 & 26,44 & 17,72 & 25,25 \\
\hline 24.11 .2018 & 03:46:07.711 & 1,61 & 1,78 & 1,59 & 26,87 & 20,26 & 24,02 \\
\hline 24.11 .2018 & 06:00:17.711 & 1,49 & 1,61 & 1,51 & 21,32 & 18,62 & 18,03 \\
\hline 24.11 .2018 & 07:35:37.711 & 1,42 & 1,57 & 1,44 & 26,09 & 20,44 & 23,51 \\
\hline 24.11 .2018 & $08: 34: 27.711$ & 1,38 & 1,46 & 1,42 & 31,34 & 26,84 & 26,77 \\
\hline 24.11 .2018 & 20:22:37.711 & 1,18 & 1,28 & 1,28 & 21,6 & 21,07 & 23,66 \\
\hline 25.11 .2018 & $00: 31: 37.711$ & 1,56 & 1,68 & 1,54 & 23,13 & 19,49 & 22,78 \\
\hline 25.11 .2018 & 05:06:37.711 & 1,67 & 1,8 & 1,66 & 23,45 & 21,57 & 22,81 \\
\hline 25.11 .2018 & 09:03:07.711 & 1,95 & 2,22 & 2,04 & 24,38 & 25,06 & 25,95 \\
\hline 25.11 .2018 & $13: 10: 47.711$ & 1,62 & 1,77 & 1,75 & 19,85 & 23,07 & 24,03 \\
\hline 25.11 .2018 & 19:39:37.711 & 1,37 & 1,5 & 1,51 & 22,17 & 20,94 & 23,06 \\
\hline 26.11 .2018 & 05:44:17.711 & 1,7 & 1,85 & 1,8 & 25,84 & 20,89 & 24,73 \\
\hline 26.11 .2018 & 10:04:17.711 & 1,1 & 1,16 & 1,12 & 30,67 & 34,83 & 35,07 \\
\hline 27.11.2018 & 10:06:17.711 & 1,14 & 1,18 & 1,22 & 20,39 & 23,64 & 22,34 \\
\hline 27.11.2018 & $12: 30: 27.711$ & 1,12 & 1,16 & 1,21 & 20,25 & 23,61 & 22,43 \\
\hline 27.11.2018 & $15: 06: 47.711$ & 1,13 & 1,18 & 1,23 & 20,24 & 20,73 & 22,37 \\
\hline 27.11 .2018 & $18: 06: 27.711$ & 1,11 & 1,16 & 1,2 & 20,28 & 20,34 & 22,34 \\
\hline 28.11.2018 & 08:06:57.711 & 1,11 & 1,16 & 1,2 & 20,36 & 21,71 & 22,36 \\
\hline 28.11.2018 & $12: 07: 07.711$ & 1,11 & 1,16 & 1,19 & 19,95 & 23,57 & 22,18 \\
\hline 28.11 .2018 & $15: 21: 07.711$ & 1,16 & 1,19 & 1,22 & 17,66 & 19,91 & 20,03 \\
\hline 28.11.2018 & $18: 19: 27.711$ & 1,23 & 1,24 & 1,25 & 18,44 & 19,59 & 20,44 \\
\hline 29.11 .2018 & 08:30:47.711 & 1,09 & 1,14 & 1,17 & 25,98 & 26,11 & 27,13 \\
\hline 29.11 .2018 & $10: 50: 17.711$ & 1,21 & 1,23 & 1,29 & 25,31 & 20,57 & 27,86 \\
\hline 29.11 .2018 & $12: 03: 57.711$ & 1,32 & 1,41 & 1,41 & 23,37 & 22,04 & 24,65 \\
\hline 29.11 .2018 & $16: 58: 27.711$ & 1,19 & 1,29 & 1,29 & 24,77 & 22,93 & 23,92 \\
\hline 30.11 .2018 & $08: 33: 27.711$ & 1,19 & 1,32 & 1,3 & 22,45 & 21,66 & 23,35 \\
\hline 30.11 .2018 & $11: 07: 47.711$ & 1,08 & 1,2 & 1,21 & 24,24 & 21,19 & 23,21 \\
\hline 30.11 .2018 & $12: 33: 37.711$ & 1,32 & 1,34 & 1,38 & 32,2 & 27,49 & 29,28 \\
\hline 30.11 .2018 & $15: 07: 17.711$ & 1,14 & 1,19 & 1,23 & 20,27 & 23,7 & 22,37 \\
\hline
\end{tabular}




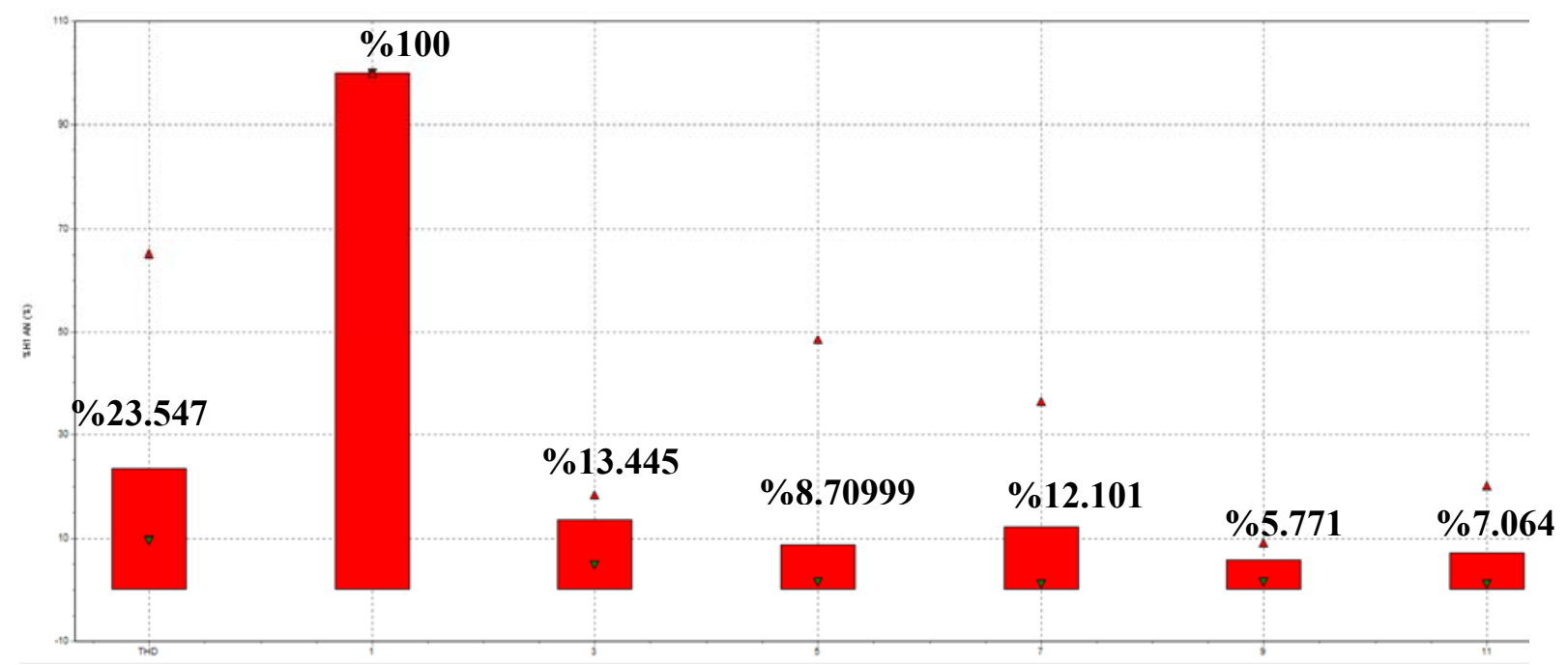

Şekil 5. Rektörlük A, B ve C Fazlarına Ait Akım Harmonik ve Akım THD Değerleri

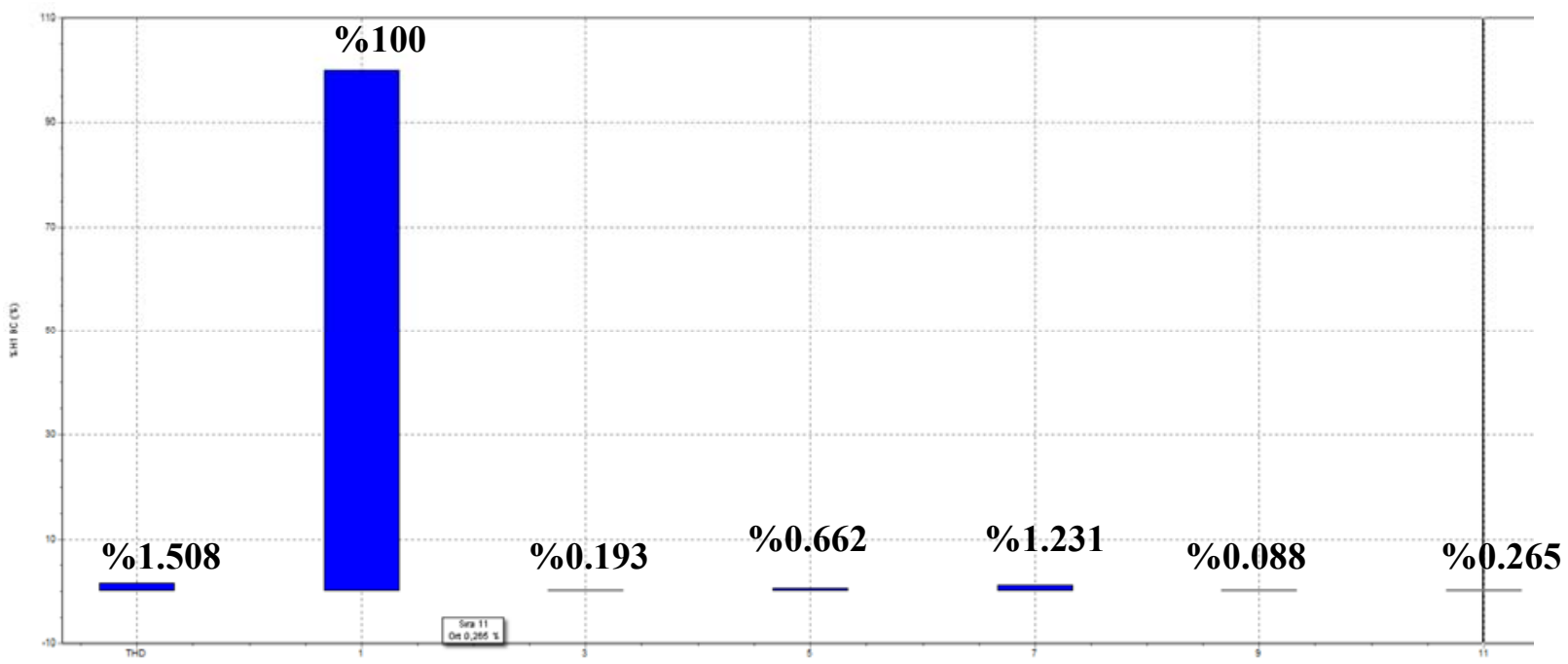

Şekil 6. Rektörlük A, B ve C Fazlarına Ait Gerilim Harmonik ve Gerilim THD Değerleri

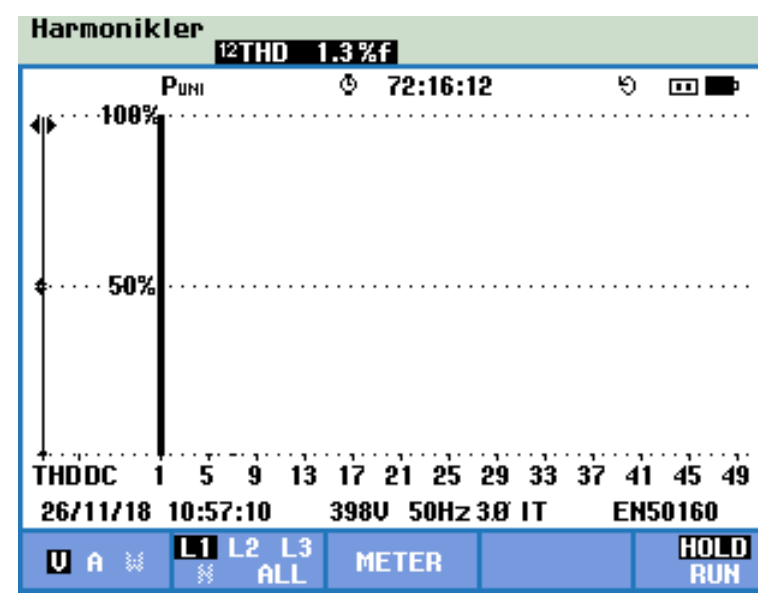

Şekil 7. Rektörlük Binasının A fazına ait Gerilim Harmoniği ve THD değerleri

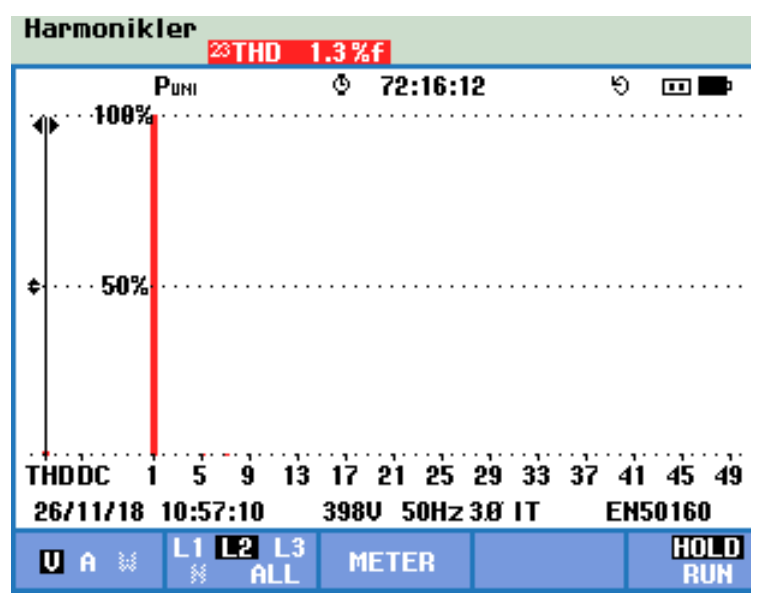

Şekil 8. Rektörlük Binasının B fazına ait Gerilim Harmoniği ve THD değerleri 


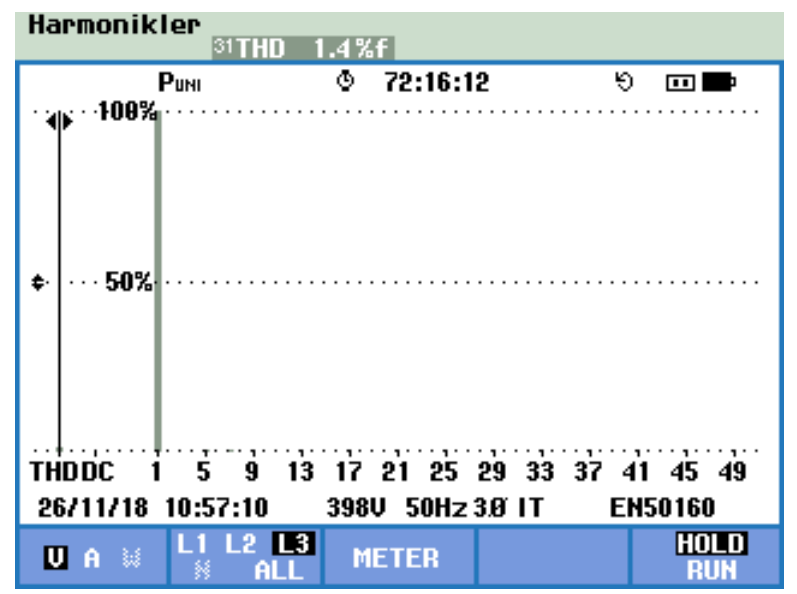

Şekil 9. Rektörlük Binasının C fazına ait Gerilim Harmoniği ve THD değerleri

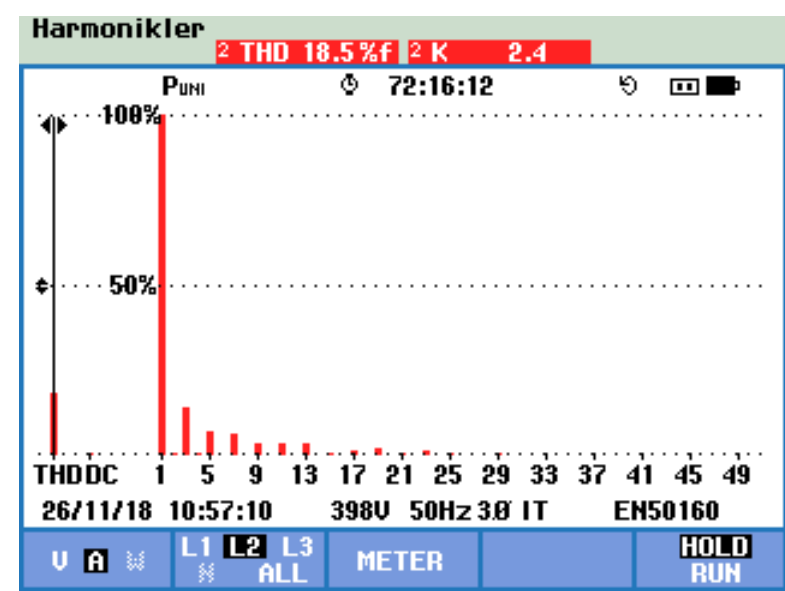

Şekil 11. Rektörlük Binasının B fazına ait Akım Harmoniği ve THD değerleri

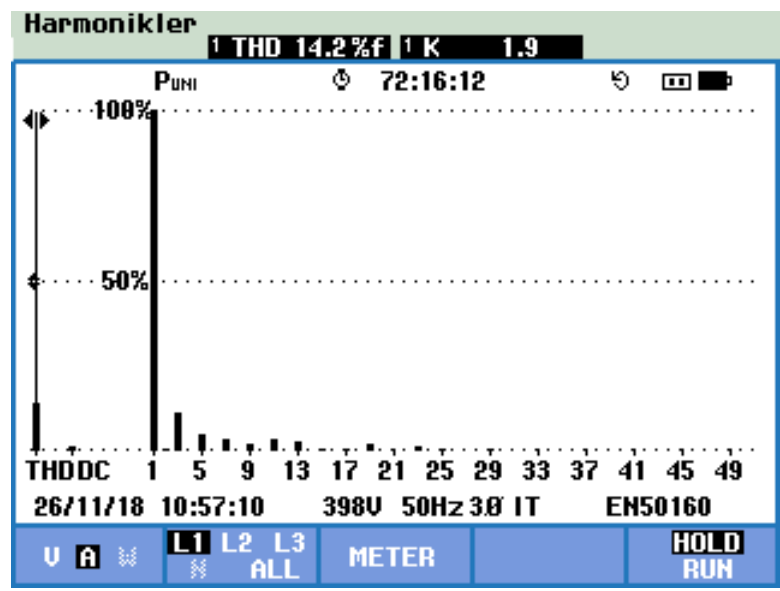

Şekil 10. Rektörlük Binasının A fazına ait Akım Harmoniği ve THD değerleri

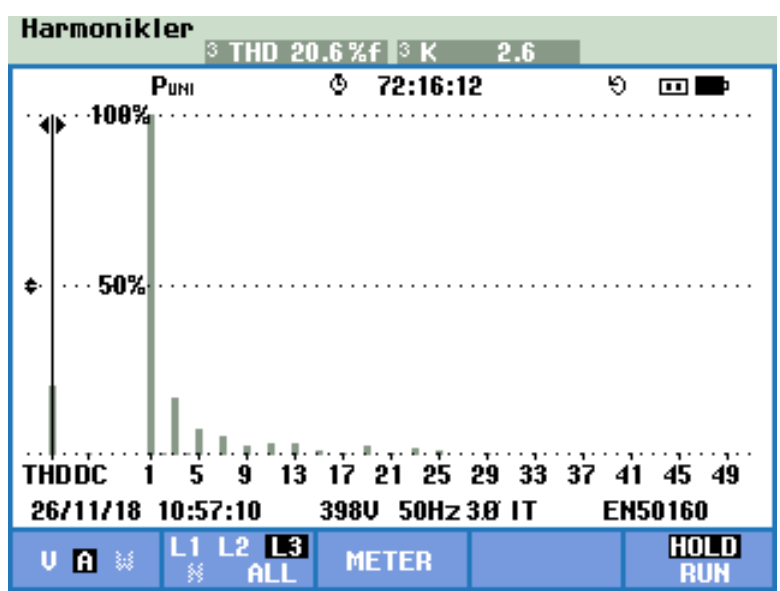

Şekil 12. Rektörlük Binasının C fazına ait Akım Harmoniği ve THD değerleri

Tablo 3.Mühendislik Fakültesi $\mathrm{THD}_{\mathrm{V}}$ ve $\mathrm{THD}_{\mathrm{I}}$ Ölçüm Sonuçları

\begin{tabular}{llcccccc}
\hline Tarih & Zaman & THDV AB & THDV BC & THDV CA & THDI A & THDI B & THDI C \\
\hline 26.11 .2018 & $12: 01: 48.167$ & 2,18 & 1,82 & 2,05 & 16,31 & 16,35 & 29,52 \\
26.11 .2018 & $12: 49: 38.167$ & 2,43 & 1,98 & 2,26 & 18,85 & 20,71 & 30,11 \\
26.11 .2018 & $14: 04: 08.167$ & 2,53 & 2,2 & 2,38 & 16,77 & 20,35 & 26,17 \\
26.11 .2018 & $16: 02: 28.167$ & 2,13 & 1,81 & 2,02 & 16,41 & 19,98 & 29,99 \\
27.11 .2018 & $08: 24: 18.167$ & 1,74 & 1,37 & 1,51 & 19,83 & 33,61 & 40,08 \\
27.11 .2018 & $08: 25: 38.167$ & 1,62 & 1,27 & 1,34 & 20,67 & 32,72 & 40,16 \\
27.11 .2018 & $10: 20: 18.167$ & 1,99 & 1,72 & 1,85 & 16,51 & 15,67 & 27,28 \\
27.11 .2018 & $11: 16: 58.167$ & 1,83 & 1,62 & 1,72 & 16,72 & 17,75 & 26,39 \\
27.11 .2018 & $13: 15: 18.167$ & 1,59 & 1,4 & 1,44 & 15,65 & 15,16 & 23,91 \\
27.11 .2018 & $16: 42: 08.167$ & 1,31 & 1,11 & 1,03 & 16,14 & 20,19 & 24,99 \\
28.11 .2018 & $08: 43: 58.167$ & 1,71 & 1,52 & 1,58 & 20,34 & 23,68 & 38,38 \\
28.11 .2018 & $09: 01: 28.167$ & 1,77 & 1,67 & 1,67 & 18,34 & 17,46 & 37,39 \\
28.11 .2018 & $11: 38: 18.167$ & 2,09 & 1,85 & 1,98 & 17,77 & 16,57 & 26,59 \\
\hline
\end{tabular}




\begin{tabular}{llllllll}
\hline 28.11 .2018 & $12: 32: 48.167$ & 2,32 & 1,82 & 2,09 & 20,5 & 17,74 & 28,87 \\
28.11 .2018 & $16: 06: 18.167$ & 2,01 & 1,83 & 1,93 & 18,44 & 17,05 & 28,61 \\
29.11 .2018 & $07: 37: 28.167$ & 1,75 & 1,33 & 1,52 & 18,12 & 28,75 & 40,58 \\
29.11 .2018 & $08: 45: 28.167$ & 2,5 & 2,1 & 2,32 & 19,45 & 21,95 & 31,77 \\
29.11 .2018 & $13: 06: 28.167$ & 2,82 & 2,33 & 2,69 & 17,25 & 17,69 & 23,48 \\
29.11 .2018 & $15: 26: 28.167$ & 2,95 & 2,44 & 2,91 & 18,86 & 17,82 & 26,66 \\
29.11 .2018 & $15: 48: 28.167$ & 2,72 & 2,29 & 2,72 & 18,99 & 17,55 & 29,34 \\
30.11 .2018 & $09: 09: 48.167$ & 2,27 & 1,89 & 2,06 & 18,75 & 22,29 & 35,85 \\
30.11 .2018 & $13: 49: 48.167$ & 2,08 & 1,95 & 2,01 & 17,31 & 17,4 & 24,3 \\
30.11 .2018 & $16: 25: 48.167$ & 1,97 & 1,74 & 1,85 & 18,72 & 18,88 & 27,86 \\
30.11 .2018 & $16: 56: 48.167$ & 2,3 & 2,01 & 2,29 & 21,19 & 23,36 & 38,52 \\
01.12 .2018 & $16: 58: 38.167$ & 1,97 & 1,75 & 1,84 & 21,25 & 21,55 & 35,53 \\
01.12 .2018 & $17: 09: 18.167$ & 1,88 & 1,59 & 1,66 & 21,2 & 22,63 & 35,82 \\
01.12 .2018 & $17: 11: 58.167$ & 1,82 & 1,51 & 1,64 & 20,88 & 23,15 & 36,33 \\
02.12 .2018 & $12: 06: 18.167$ & 2,27 & 1,89 & 2,17 & 15,44 & 16,16 & 28,2 \\
02.12 .2018 & $13: 08: 28.167$ & 2,34 & 1,95 & 2,21 & 16,6 & 17,19 & 26,85 \\
02.12 .2018 & $14: 15: 08.167$ & 2,62 & 2,22 & 2,51 & 17,4 & 18,34 & 27,63 \\
03.12 .2018 & $12: 02: 38.167$ & 2,4 & 1,97 & 2,33 & 16,65 & 17,49 & 29,87 \\
03.12 .2018 & $13: 06: 38.167$ & 2,47 & 2,05 & 2,34 & 19,63 & 22,73 & 28,2 \\
03.12 .2018 & $14: 19: 08.167$ & 2,73 & 2,29 & 2,64 & 17,53 & 20,72 & 29,68 \\
03.12 .2018 & $16: 08: 38.167$ & 2,52 & 1,97 & 2,35 & 19,1 & 23,33 & 32,21 \\
03.12 .2018 & $17: 02: 08.167$ & 2,3 & 1,86 & 2,19 & 22,47 & 23,2 & 37,59 \\
\hline & & & & & & &
\end{tabular}

Tablo 3 ve şekil 18-19-20'de görüldüğü gibi, 1.Ölçüm noktasında (Mühendislik Fakültesi Binası) yapılan ölçümlerin her fazına ait gerilim ve akımların toplam harmonik değerleri verilmiştir. A, B ve C faz gerilimlerde oluşan THD uygun sınırlarda olmakla birlikte Tablo 3'de ortalama \%2 civarında olduğu görülmektedir. Şekil 15-17'de saat 15:59:55' de A ve C fazında \%2.6'lik gerilim harmoniği, Şekil 16’ da görüldüğü gibi B fazında \%2.3 'lük gerilim harmonik distorsiyonu belirlenmiştir. Ayrıca Şeki113-14'de A, B ve C fazlarına ait akım harmonik ve akım THD değerleri ile gerilim harmonik ve gerilim THD değerleri verilmiştir. 


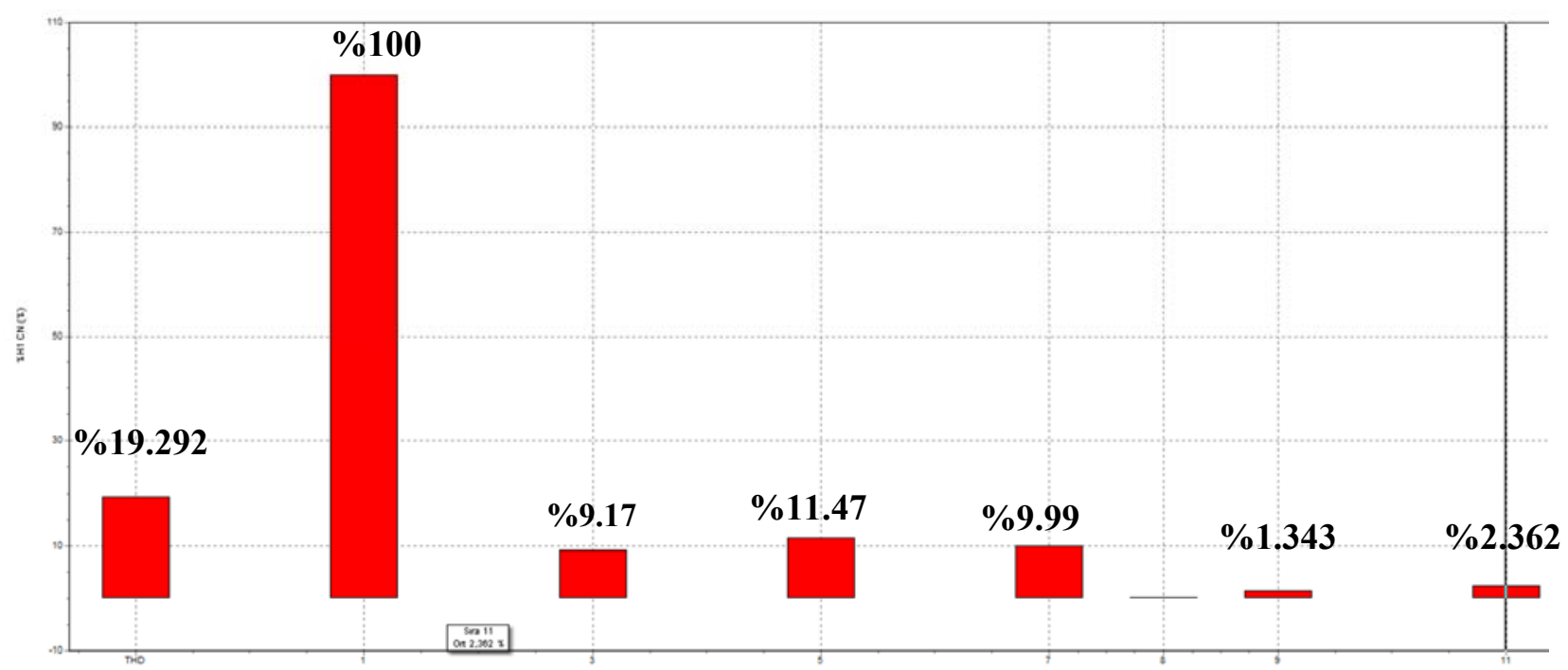

Şekil 13. Mühendislik Fakültesi, A, B ve C Fazlarına Ait Akım Harmonik ve Akım THD Değerleri

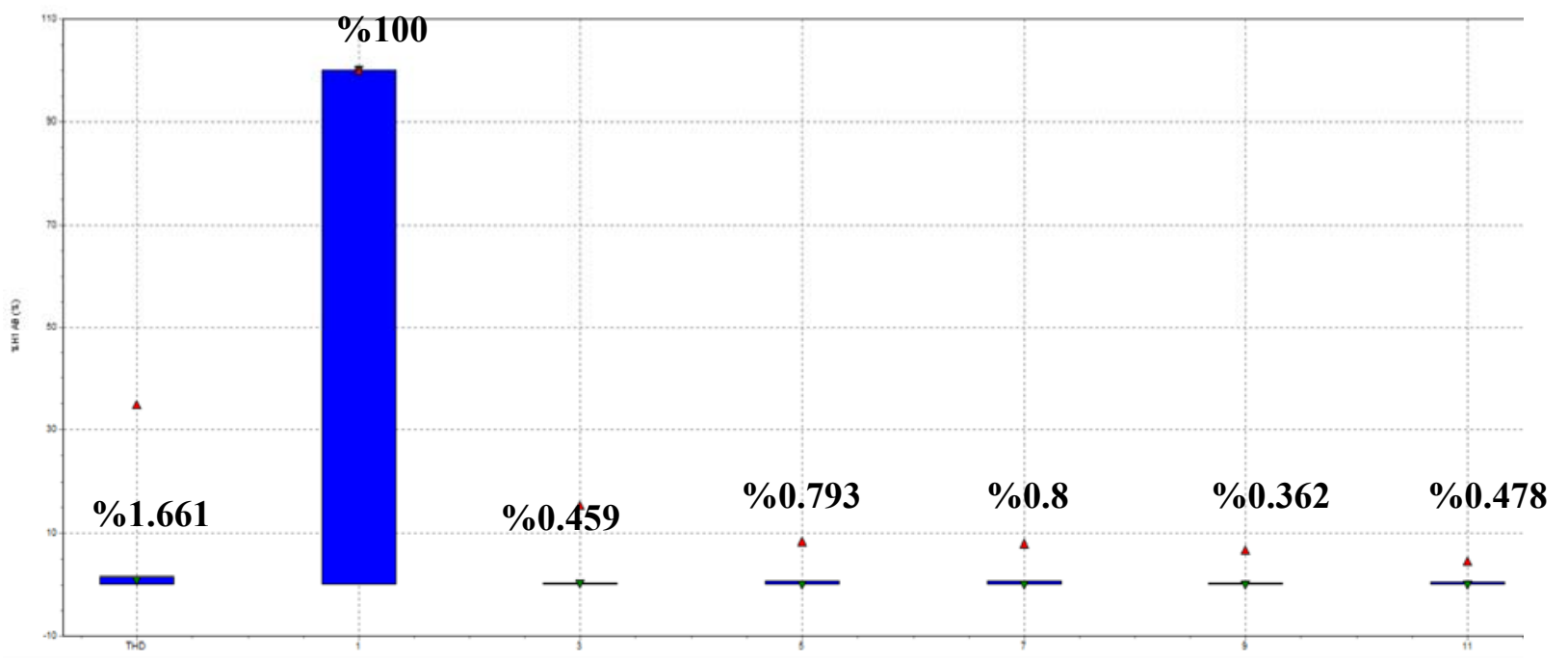

Şekil 14. Mühendislik Fakültesi, A, B ve C Fazlarına Ait Gerilim Harmonik ve Gerilim THD

Değerleri

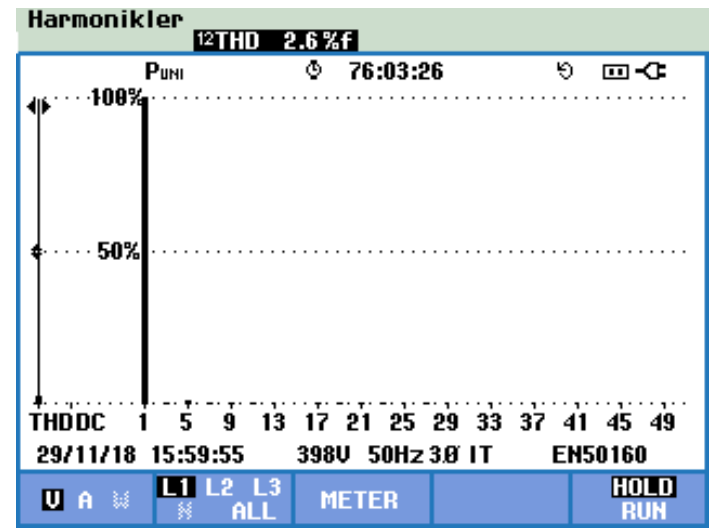

Şekil 15. Mühendislik Fakülte Binasının A fazına ait Gerilim Harmoniği ve THD değerleri

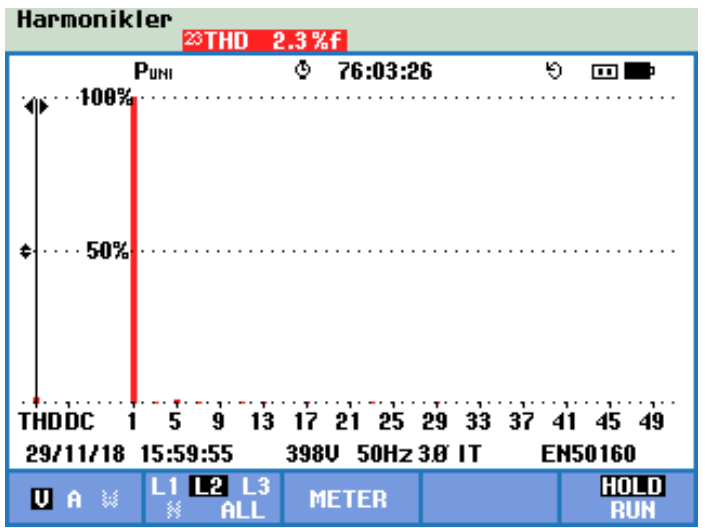

Şekil 16. Mühendislik Fakülte Binasının B fazına ait Gerilim Harmoniği ve THD değerleri 


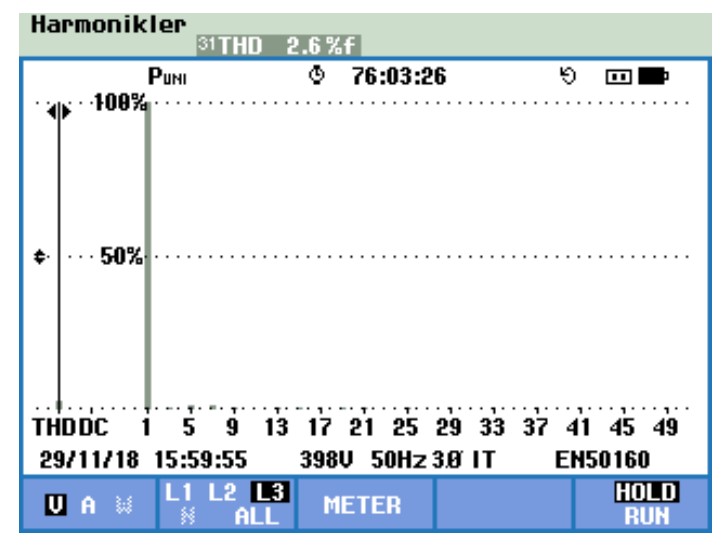

Şekil 17. Mühendislik Fakülte Binasının C fazına ait Gerilim Harmoniği ve THD değerleri

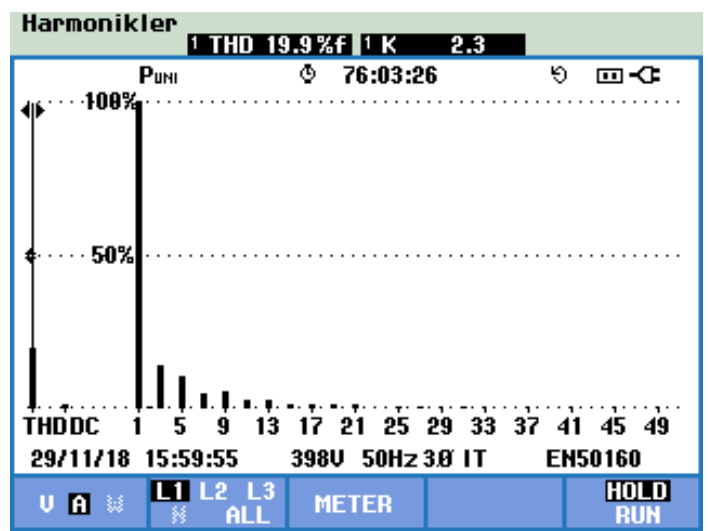

Şekil 18. Mühendislik Fakülte Binasının A fazına ait Akım Harmoniği ve THD değerleri

Şekil 18-19-20‘de GKA cihazı ile ölçümlenen sonuçlara baktığımızda Mühendislik Fakültesinde, A fazında belirgin olarak 3., 5., 7., 9.,11 ve 13. harmonikler tespit edilmiş olup faz akımı toplam harmonik bozulma değeri yaklaşık olarak THD \%19.9, B fazında 3., 5., 7., 9., 11.,13., 15 ve 17. harmonikler belirlenmiş olup faz akımı toplam harmonik bozulma değeri yaklaşık olarak THD \%20.7 ve C fazında ise 3., 5., 7. ve 13. harmonikler bulunmakta faz akımı toplam harmonik bozulma değeri yaklaşık olarak THD \%27.5 'dir.

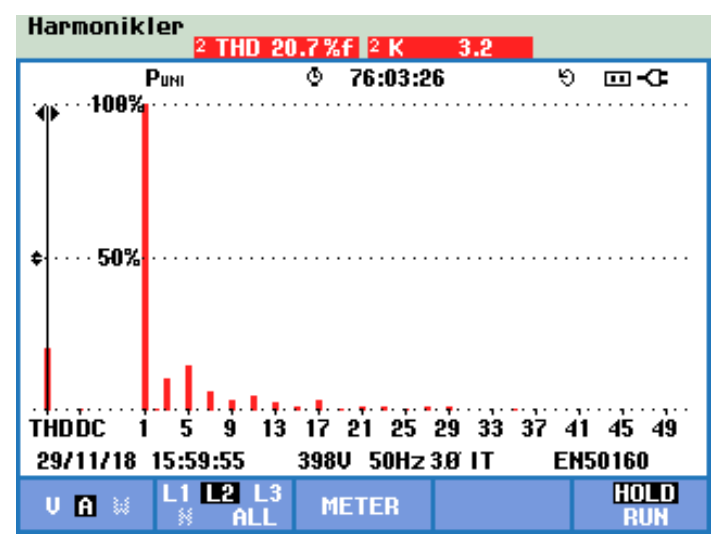

Şekil 19. Mühendislik Fakülte Binasının B fazına ait Akım Harmoniği ve THD değerleri

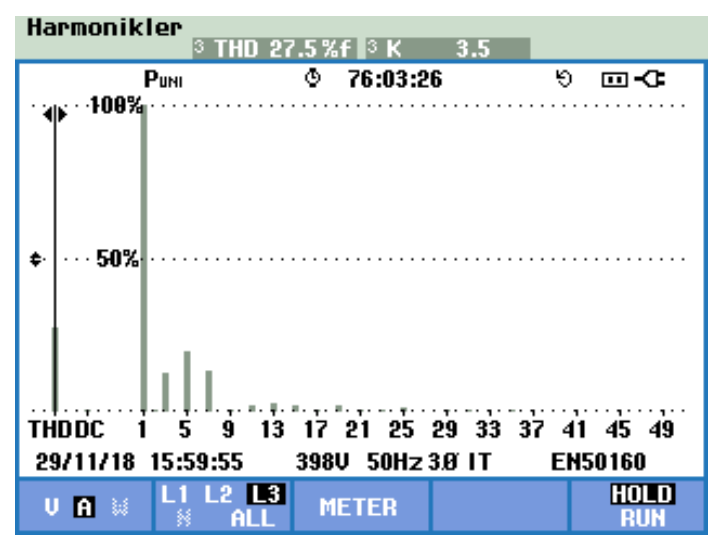

Şekil 20. Mühendislik Fakülte Binasının C fazına ait Akım Harmoniği ve THD değerleri

Tablo 4 ve Şekil 20-21 'de, Araştırma Merkez Laboratuvarı binasında yapılan ölçümlerin her fazına ait akım harmonik ve akım THD değerleri ile gerilim harmonik ve gerilim THD değerleri verilmiştir. A, B ve C faz gerilimlerde oluşan THD uygun sınırlarda olmakla birlikte Tablo 4'de ortalama \%1.25 civarında gerilim harmonik distorsiyonu olduğu görülmektedir. Şekil23-24`de B ve C fazında \%1.1'lik gerilim harmoniği, Şekil 22'de görüldüğü gibi A fazında \%1.3 'lük gerilim harmonik distorsiyonu belirlenmiştir. Ayrıca Şekil 20-21'de A, B ve C fazlarına ait akım harmonik ve akım THD değerleri ile gerilim harmonik ve gerilim THD değerleri verilmiştir. 
Tablo 4. Araştırma Merkez Laboratuvarı THDV ve THDI Ölçüm Sonuçları

\begin{tabular}{|c|c|c|c|c|c|c|c|}
\hline Tarih & Zaman & THDV AB & THDV BC & THDV CA & THDI A & THDI B & THDI C \\
\hline 29.11 .2018 & $16: 16: 33.605$ & 1,03 & 0,97 & 0,99 & 10,12 & 11,6 & 9,78 \\
\hline 29.11 .2018 & 17:03:03.605 & 0,97 & 0,92 & 1,01 & 10,12 & 24,73 & 10,37 \\
\hline 29.11 .2018 & 17:09:13.605 & 0,94 & 0,88 & 0,95 & 10,26 & 22,64 & 15,26 \\
\hline 29.11 .2018 & 18:00:53.605 & 1,09 & 1,04 & 1,08 & 11,73 & 25,08 & 17,33 \\
\hline 29.11 .2018 & 18:53:53.605 & 1,12 & 1,1 & 1,16 & 16,53 & 26,09 & 24,16 \\
\hline 29.11 .2018 & 19:51:03.605 & 1,13 & 1,09 & 1,18 & 12,19 & 19,81 & 23,9 \\
\hline 29.11.2018 & $21: 18: 23.605$ & 1,13 & 1,05 & 1,1 & 11,95 & 20,87 & 23,33 \\
\hline 30.11 .2018 & 00:11:43.605 & 1,31 & 1,27 & 1,34 & 11,82 & 17,94 & 23,24 \\
\hline 30.11 .2018 & 03:51:03.605 & 1,28 & 1,22 & 1,3 & 15,23 & 19,19 & 22,89 \\
\hline 30.11 .2018 & 04:20:03.605 & 1,37 & 1,3 & 1,39 & 14,73 & 17,84 & 22,82 \\
\hline 30.11 .2018 & 06:19:23.605 & 1,32 & 1,32 & 1,37 & 15,55 & 19,43 & 23,17 \\
\hline 30.11 .2018 & 08:08:13.605 & 1,06 & 1,05 & 1,11 & 12,35 & 18,74 & 18,89 \\
\hline 30.11 .2018 & $12: 05: 43.605$ & 0,98 & 0,95 & 1,05 & 10,35 & 19,3 & 23,65 \\
\hline 30.11 .2018 & $15: 30: 33.605$ & 1,05 & 1,02 & 1,04 & 10,61 & 11,91 & 9,34 \\
\hline 30.11 .2018 & 16:03:13.605 & 1,06 & 1,04 & 1,1 & 10,82 & 12,85 & 15,52 \\
\hline 30.11 .2018 & $19: 13: 43.605$ & 1,12 & 1,06 & 1,15 & 12,39 & 24,95 & 23,84 \\
\hline 30.11 .2018 & $19: 24: 53.605$ & 1,15 & 1,09 & 1,19 & 13,03 & 26,31 & 23,89 \\
\hline 1.12 .2018 & 04:48:43.605 & 1,28 & 1,19 & 1,37 & 24,67 & 36,94 & 23,79 \\
\hline 1.12 .2018 & 05:05:43.605 & 1,33 & 1,24 & 1,4 & 24,61 & 36,88 & 24,94 \\
\hline 2.12 .2018 & 08:07:23.605 & 2,47 & 2,52 & 2,58 & 27,03 & 29,43 & 22,59 \\
\hline 2.12.2018 & 08:32:13.605 & 2,61 & 2,68 & 2,71 & 28,35 & 34,39 & 22,61 \\
\hline 2.12.2018 & $11: 29: 23.605$ & 1,63 & 1,57 & 1,76 & 22,19 & 22,43 & 19,13 \\
\hline 3.12 .2018 & 07:25:03.605 & 1,3 & 1,32 & 1,4 & 23,22 & 29,91 & 22,15 \\
\hline 3.12 .2018 & 07:30:43.605 & 1,26 & 1,25 & 1,36 & 24,32 & 28,89 & 21,79 \\
\hline 3.12 .2018 & 08:21:03.605 & 1,08 & 1,06 & 1,17 & 17,35 & 18,98 & 21,74 \\
\hline 04.12 .2018 & 01:15:43.605 & 1,31 & 1,24 & 1,34 & 11,31 & 20,72 & 22,57 \\
\hline 04.12 .2018 & 02:03:03.605 & 1,29 & 1,2 & 1,25 & 11,57 & 17,75 & 23,22 \\
\hline 04.12 .2018 & 04:06:15.605 & 1,27 & 1,35 & 1,29 & 1,36 & 14,96 & 18,21 \\
\hline 05.12 .2018 & 22:41:13.605 & 1,19 & 1,11 & 1,16 & 12,02 & 21,37 & 23,38 \\
\hline 05.12 .2018 & 23:02:53.605 & 1,18 & 1,11 & 1,17 & 11,54 & 21,71 & 23,55 \\
\hline 05.12 .2018 & 00:06:03.605 & 1,34 & 1,3 & 1,38 & 11,85 & 18,8 & 18,64 \\
\hline 05.12 .2018 & 01:46:33.605 & 1,32 & 1,25 & 1,31 & 11,79 & 16,86 & 23,3 \\
\hline 06.12 .2018 & 03:45:53.605 & 1,8 & 1,82 & 1,95 & 23,95 & 31,43 & 22,41 \\
\hline 06.12 .2018 & 05:07:53.605 & 1,86 & 1,89 & 2,03 & 24,29 & 28,19 & 22,58 \\
\hline 06.12 .2018 & 06:20:43.605 & 1,73 & 1,77 & 1,85 & 25,31 & 35,89 & 22,31 \\
\hline 06.12 .2018 & 07:11:53.605 & 1,45 & 1,48 & 1,56 & 25,01 & 26,95 & 21,9 \\
\hline 06.12 .2018 & 08:17:53.605 & 1,08 & 1,06 & 1,15 & 17,4 & 19,12 & 21,78 \\
\hline 06.12 .2018 & 09:32:53.605 & 0,96 & 0,97 & 1,05 & 9,84 & 11,74 & 12,47 \\
\hline
\end{tabular}




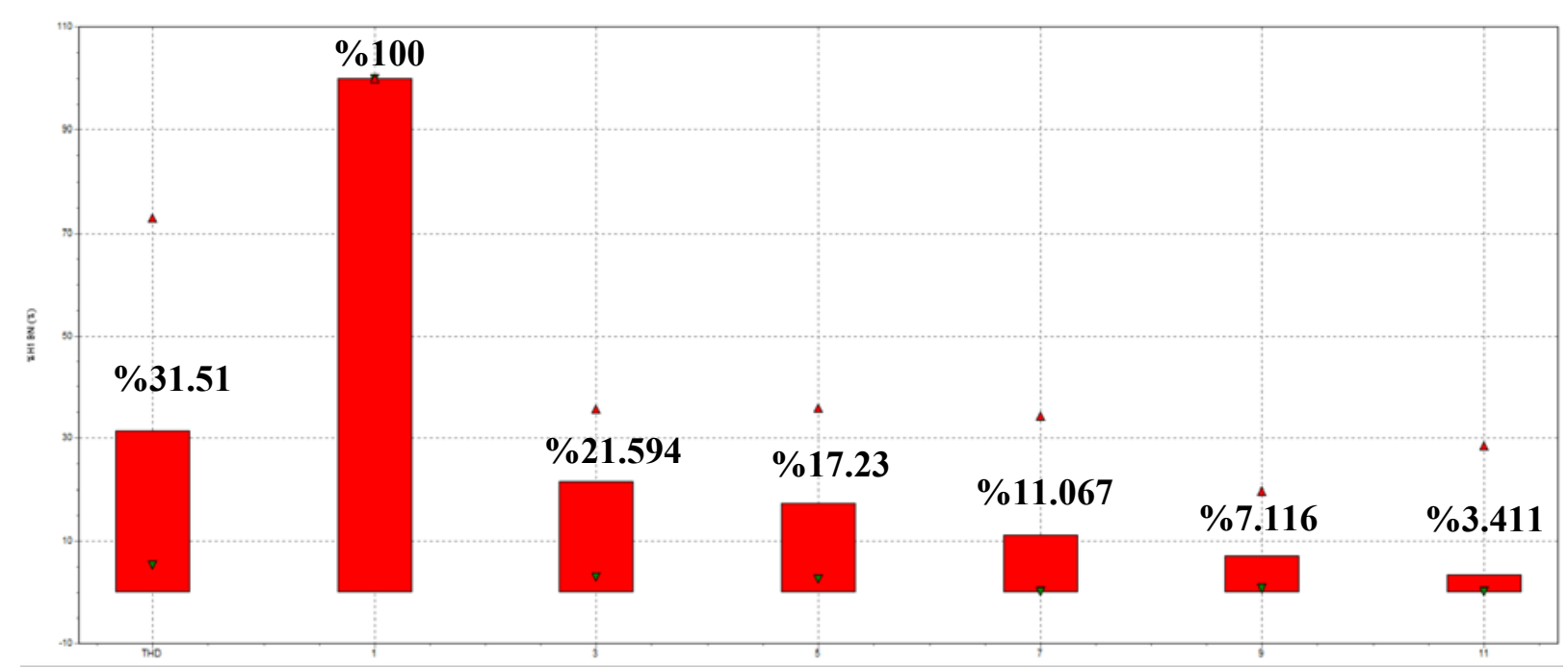

Şekil 21. Araştırma Merkez Laboratuvarı, A, B ve C Fazlarına Ait Akım Harmonik ve Akım THD Değerleri

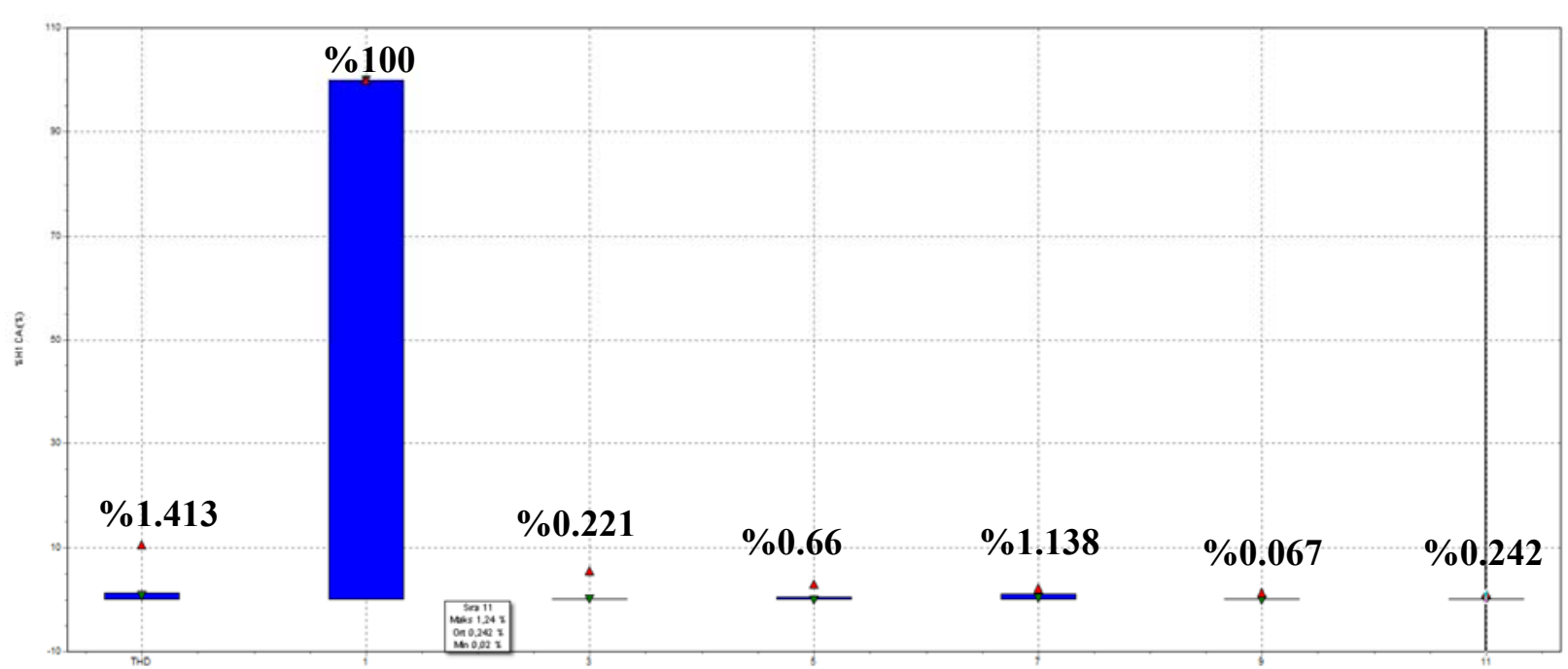

Şekil 22. Araştırma Merkez Laboratuvarı, A, B ve C Fazlarına Ait Gerilim Harmonik ve Gerilim THD Değerleri

Şekil 26-27-28‘de GKA cihazı ile ölçümlenen sonuçlara baktığımızda Araştırma Merkez Laboratuvarında, A fazında belirgin olarak 3., 5., 7. ve 9. harmonikler tespit edilmiş olup faz akımı toplam harmonik bozulma değeri yaklaşık olarak THD \%10.5, B fazında 3., 5., 7. ve 9. harmonikler belirlenmiş olup faz akımı toplam harmonik bozulma değeri yaklaşık olarak THD \% 11.1 ve C fazında ise 3., 5., 7. 9., 11. ve 13. harmonikler bulunmakta faz akımı toplam harmonik bozulma değeri yaklaşık olarak THD \%14.1'dir. 


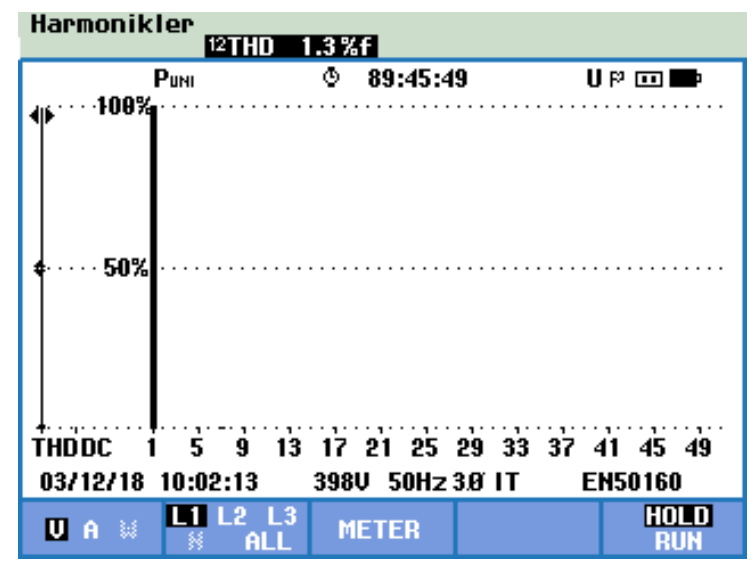

Şekil 23. Araştırma Merkez Laboratuvarı A fazına ait Gerilim Harmoniği ve THD değerleri

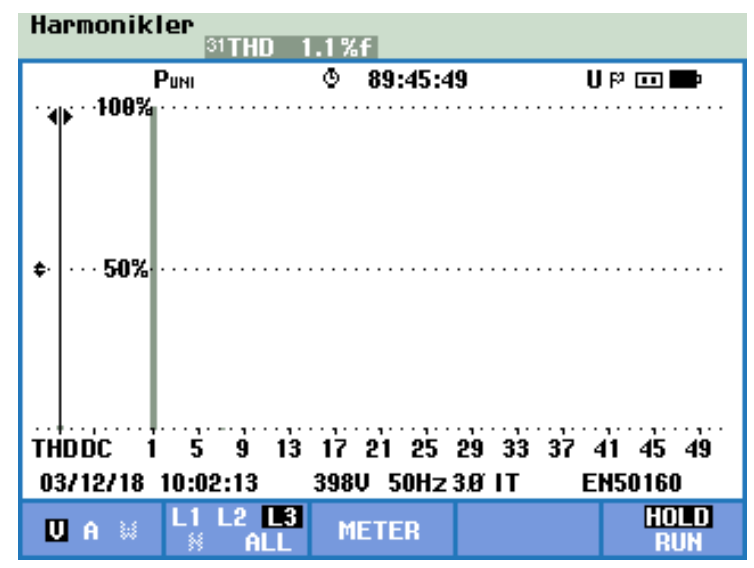

Şekil 25. Araştırma Merkez Laboratuvarı C fazına ait Gerilim Harmoniği ve THD değerleri

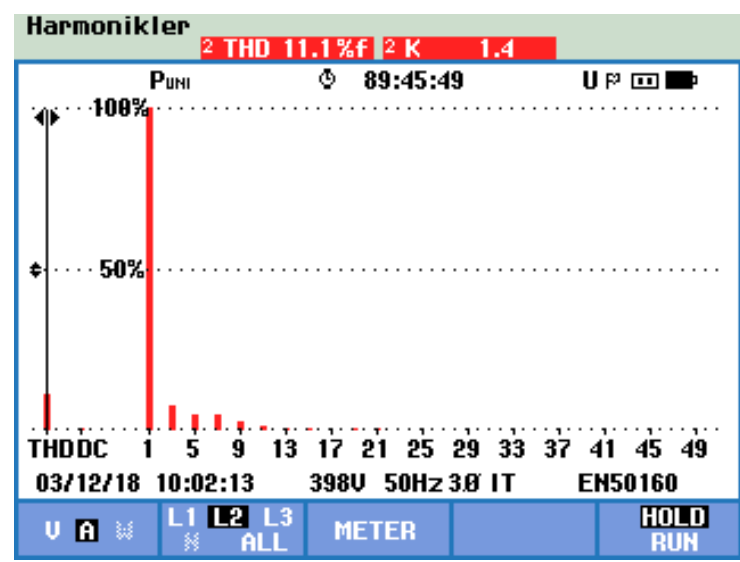

Şekil 27. Araştırma Merkez Laboratuvarı B fazına ait Akım Harmoniği ve THD değerleri

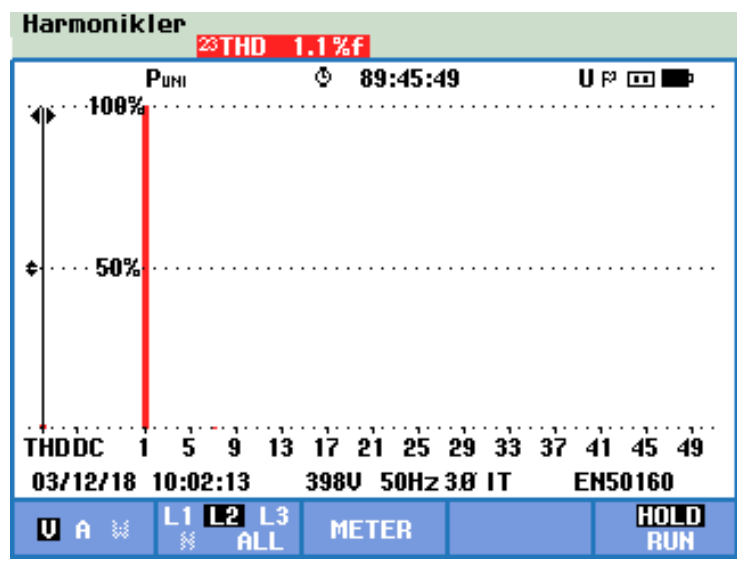

Şekil 24. Araştırma Merkez Laboratuvarı B fazına ait Gerilim Harmoniği ve THD değerleri

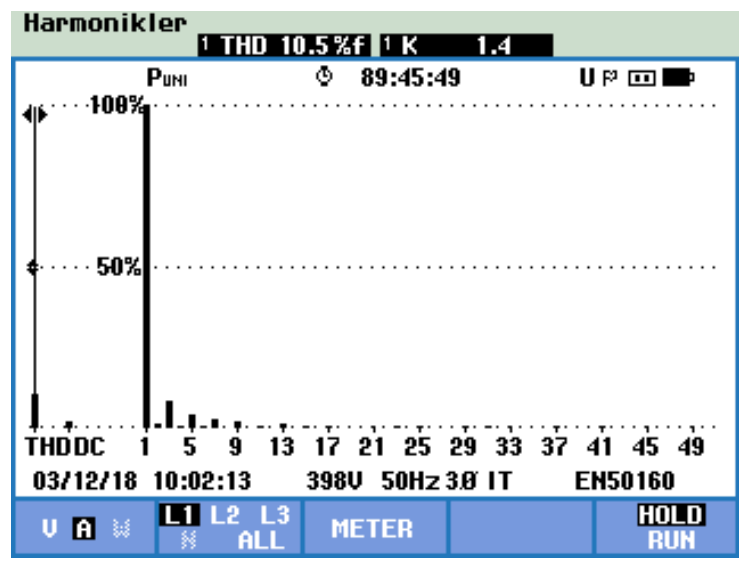

Şekil 26. Araştırma Merkez Laboratuvarı A fazına ait Akım Harmoniği ve THD değerleri

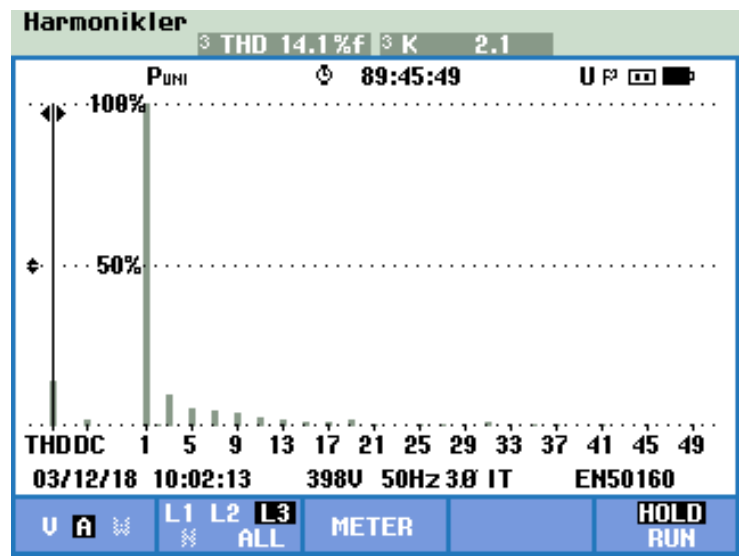

Şekil 28. Araştırma Merkez Laboratuvarı C fazına ait Akım Harmoniği ve THD değerleri

Üniversitemize ait binaların tamamının enerji takibi bir sistem üzerinden yapılmaktadır. Enerji takip sistemi üzerinden alınan veriler ile güç kalitesi analizörü ölçüm sonuçlarının yaklaşık olarak aynı değerlerde olduğu, Şekil 29’ da görülmektedir. 


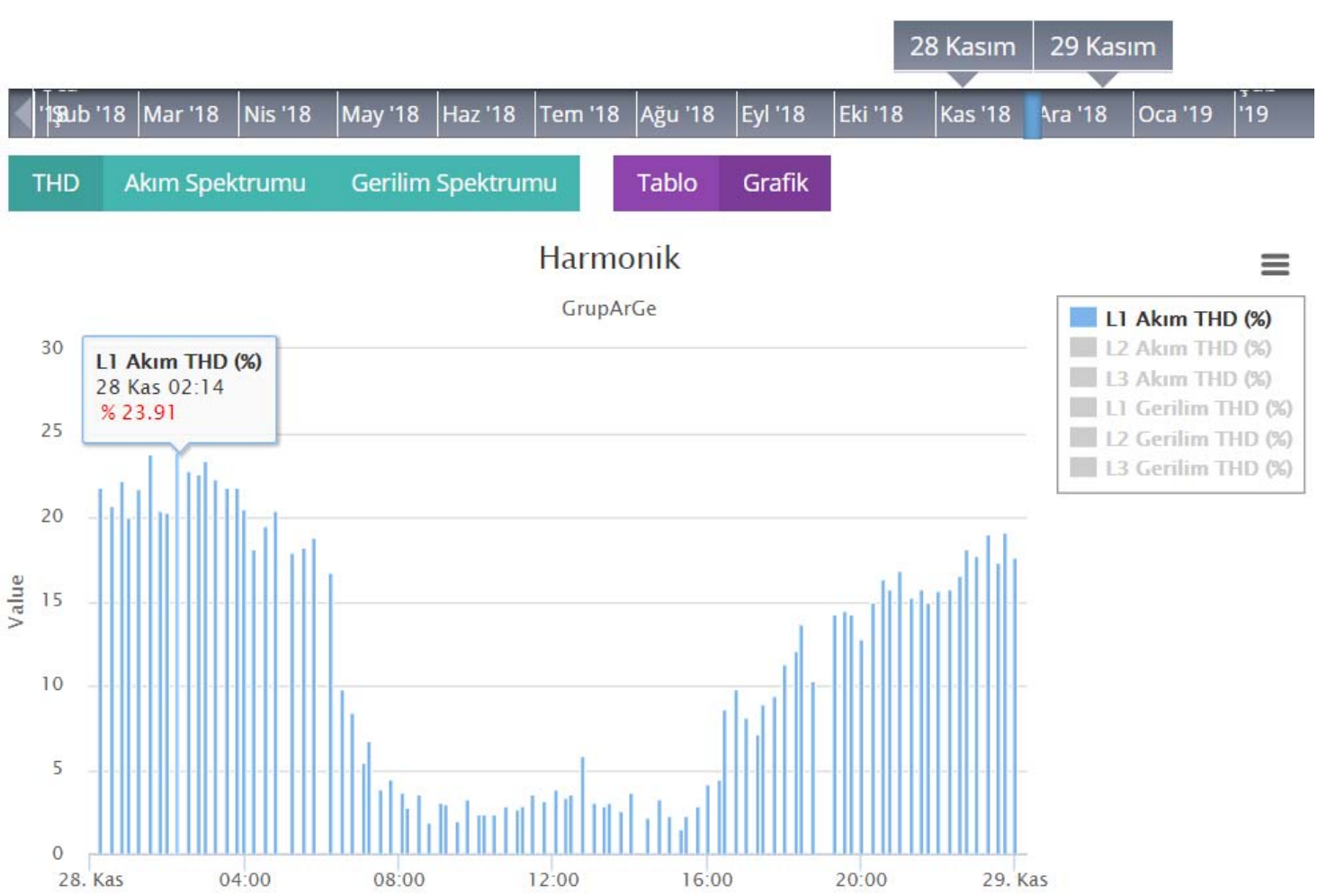

Şekil 29. Enerji Takip Sisteminde Alınan A Fazının Akım THD Spektrumu

Şekil 30’ da Mühendislik Fakültesi binasının, mesai başlangıcında A fazının akım THD \%3,66 ve Şekil 31'de mesai bitiminde A fazının akım THD \%8,14 olduğu görülmektedir Mesai saatleri dışında A fazının akım THD Şekil 29'da görüldüğü gibi \%23,91 değerindedir.

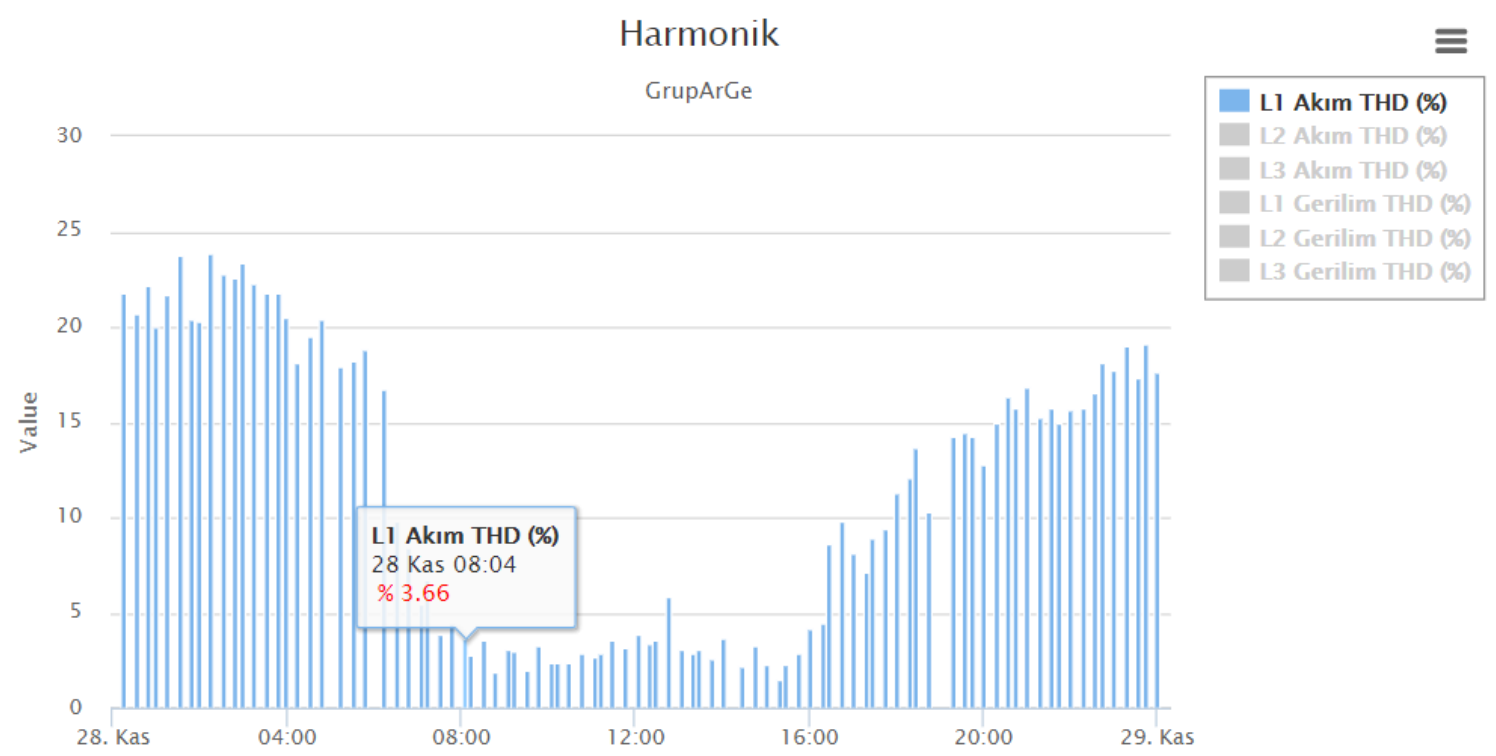

Şekil 30. Mesai Başlangıcında Mühendislik Fakültesinde Alınan A Fazının Akım THD Spektrumu 


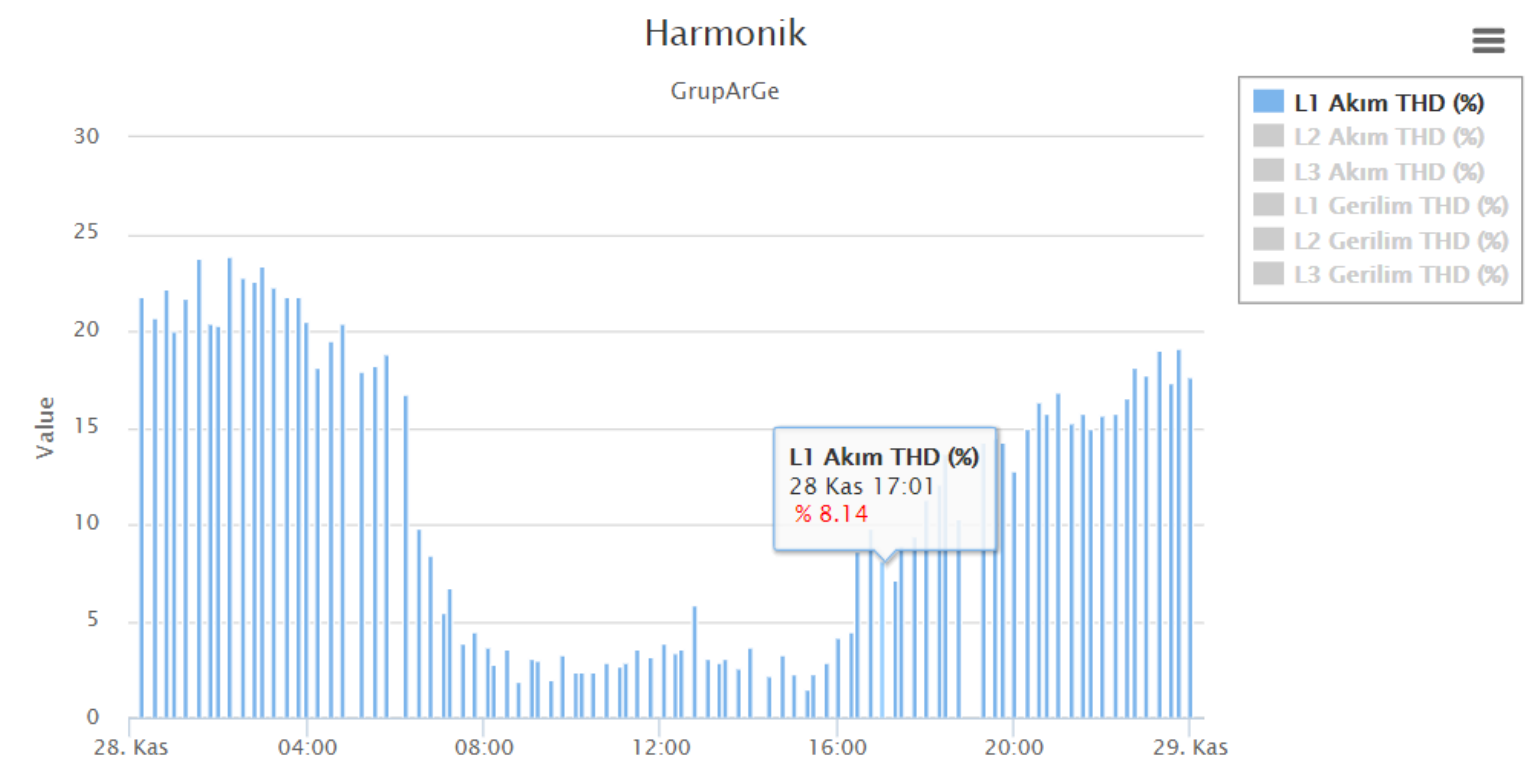

Şekil 31. Mesai Bitiminde Mühendislik Fakültesinde Alınan A Fazının Akım THD Spektrumu

Ölçümler, binalardaki kompanzasyon panoları devre dışı bırakılarak 7 gün süreyle alınmıştır. Kampüs genelindeki ana hat kapasitesini dengelemek için binalarda direkt bağlı reaktörler bulunmaktadır. Mühendislik Fakültesi ve Rektörlük binalarında olmayan, Merkezi Araştırma Laboratuvarında mevcut 2 tane 2,5 kVAr değerinde reaktör bağlıdır.

Binaları besleyen trafoların gücü 1600 kVA olup çekilen akımın en büyük değeri 60 A olarak tespit edilmiştir. Şekil 29’ de görüldüğü gibi gece mesai saatleri dışında akım THD değeri yükselirken, Şekil 30 ve Şekil 31'de ise mesai saati içerisinde bu değerin çok düştüğü belirlenmiştir. Üniversite kampüs alanının yeni kurulması ve binaların besleme trafolarının çok yüksek güç değerinde seçilmesi ( en az 2 binayı besleyecek şekilde planlanmıştır.) yüksüz durumda olan transformatörün kayıplarının artmasına yol açmaktadır. Güç sistemlerindeki en önemli elemanlardan olan transformatörler bilinen en eski nonlineer elemanlardır. Bunların harmonik üretme özelliğgi, demir çekirdeğin mıknatıslanma karakteristiğinin lineer olmamasından, yani transformatörün doymasından kaynaklanmaktadır. Transformatörün çekirdeğinin mıknatıslanma karakteristiği lineer özelliğe sahip olmadığından uygulanan sinüsoidal uyarma akımı sonucu sinüsoidal akı ve gerilim oluşmaktadır. Transformatörün boşta çalışma akımı, demir kayıplarına ait akım ile harmonik bileşenler içeren mıknatıslanma akımının toplamından oluşur. Boşta çalışan transformatör yüksüz olmasına rağmen mıknatıslanma akımı nedeniyle, nonsinüsoidal (harmonikli) akım çeker diğer bir deyişle harmonik üretir. Motor veya transformatörler yüklendiğinde daha az harmonik üretecektir. Çünkü uyarma gerilimi, sistemdeki gerilim düşümünden dolayı daha az olacaktır. Mıknatıslanma akımı harmonikleri günün erken saatlerinde en yüksek seviyeye ulaşacak, çünkü bu halde sistemdeki yük az olduğundan gerilim yükselmekte ve aşırı uyarma meydana gelmektedir. Aşırı uyarmayla oluşan akım harmoniklerinde ise 3., 5. ve 7. harmonikler etkili olurlar. 


\section{Sonuçlar ve Öneriler}

$\mathrm{Bu}$ çalışmada Yalova Üniversitesi Merkez Kampüsünde güç kalitesi problemlerinin belirlenmesi için Fluke 435-II Üç Fazlı Enerji ve Güç Kalitesi Analizörü (GKA) cihazıyla, Rektörlük-Mühendislik Fakültesi ve Araştırma Merkez Lab. binalarında meydana gelen RMS olayları düşme, yükselme, geçici dalgalanma, kesinti, hızlı gerilim değişiklikleri, frekans dalgalanmaları ve toplam harmonik distorsiyonu parametreleri 7 gün aralıklarla ölçülmüştür. Ölçümler sonucunda, harmoniklerin var olduğu ve Uluslararası IEC 519-1992 standart içinde kabul edilen harmonik bozulmanın, THDV gerilim için \% 3 değerinin altında, THDI akım için \% 5 in üzerinde olduğu gözlemlenmiştir. Kampüste yapılan ölçümlerde elde edilen sonuçlar incelendiğinde, her birimde farklı enerji kalitesi olayları olduğu görülmüştür. Bu kalite olayları değerlendirilirken, tabiat şartları, besleme şebekesindeki anahtarlamalar, dizel-jeneratörlerin devreye zamanında girip çıkmadığının etkisi ve kesintisiz güç kaynaklarının etkinliğinin de benzer şekilde incelenmesi gerekir.

Yapılan ölçümler ve tüm kayıt verileri incelendiğinde, Yalova Üniversitesi Merkez Kampüsünün enerji kalitesinde ciddi kalite problemleri olduğu ortaya çıkmıştır. Yeni bir üniversitesi olması ve kampüs elektrik alt yapısında çalışan birçok cihazın özellikle bina besleme trafolarının yüksek güç değerlerinde alındığı tespit edilmiştir. Yüksek güçte tercih edilmesi ve yüklenme kapasitesinin çok düşük olması sistemde yüksek değerde harmonik oluşumuna neden olmaktadır. Bu yüksek harmonikler zamanla kondansatör tahribatına, elektronik kart arızalarına, bilgisayar arızalarına, bilgisayarlarda veri kayıplarına neden olmaktadır. Standartlar göz önünde bulundurulduğunda harmoniklerin etkileri minimuma indirilir, sistem üzerindeki etkileri tamamen kaldırılamaz. Ancak çok daha düşük seviyelere çekilerek sisteme zarar vermesi engellenebilir. Çözüm olarak, elektrik sisteminde kullanılan harmonik üreten cihazların tasarım aşamasında, harmonik üretmeyecek şekilde ya da sisteme harmonik vermeyecek şekilde filtreli imal edilmelidir. $\mathrm{Bu}$ gerçekleştirilemiyorsa ya da sistemdeki cihazlar yenilenemiyorsa o zaman harmonik sorununun üretildiği yerde yok edilmelidir. Bunun için her bir harmonik seviyesine ayrı ayrı pasif filtreleme veya aktif filtreleme çalışmaları yapılmalıdır. Ayrıca harmonikli devrelerde kullanılacak trafoların bağlantı grupları: Dyn11 yerine Dyn5 kullanılmasında yarar vardır. Çünkü; Dyn11 Trafonun OG. Girişi ile AG. Çıkışında 330 Dyn5 Trafonun OG. Girişi ile AG. Çıkışında $150^{\circ}$ faz farkı vardır. Bu da harmoniklerin yok edilmesinde büyük önem taşır. 


\section{Kaynaklar}

Kesler, M., (2010). "Birleşik Güç Kalite Düzenleyicisinin Senkron Referans Yapı Tabanlı Uygulama Tasarımı ve Analizi”, Yayınlanmış Doktora Tezi, Kocaeli Üniversitesi, Fen Bilimleri Enstitüsü, Kocaeli.

Kürker, F., Taşaltın, R., (2016) “Elektrik Tesislerinde Harmoniklerin Meydana Getirdiği Kayıpların Analizi”, Adıyaman Üniversitesi, Mühendislik Bilimleri Dergisi, Adıyaman 21-38.

Fluke 434-II/435-II/437-II Üç Fazlı Enerji ve Güç Kalitesi Analizörü Kullanım Kılavuzu, TR Ocak 2012 rev. 1 06/12, Fluke Corporation, 2012; 3:1- 3.

ABB, Technical Application Papers No.8, 64s.

https://library.e.abb.com/public/4704e67320c08992c1257870002e4700/1SDC007107G0202.pdf

(Erişim Tarihi 01.04.2019) 